Portland State University

PDXScholar

\title{
Effects of surrounding land use on plant species composition in urban forest fragments
}

Bruce Michael Barbarasch

Portland State University

Follow this and additional works at: https://pdxscholar.library.pdx.edu/open_access_etds

Part of the Plant Sciences Commons

Let us know how access to this document benefits you.

\section{Recommended Citation}

Barbarasch, Bruce Michael, "Effects of surrounding land use on plant species composition in urban forest fragments" (2005). Dissertations and Theses. Paper 4130.

https://doi.org/10.15760/etd.6013

This Thesis is brought to you for free and open access. It has been accepted for inclusion in Dissertations and Theses by an authorized administrator of PDXScholar. Please contact us if we can make this document more accessible: pdxscholar@pdx.edu. 


\section{THESIS APPROVAL}

The abstract and thesis of Bruce Michael Barbarasch for the Master of Science in

Environmental Sciences and Resources were presented May 4, 2005, and accepted by the thesis committee and the department.

COMMITTEE APPROVALS:

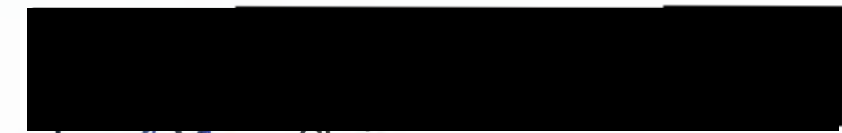

Joseph haser, Chair

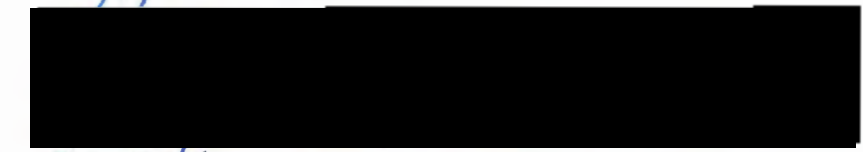

Roy Koch

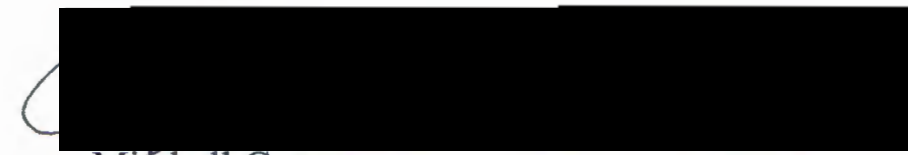

Mitchell Cruzan

Representative of the Office of Graduate Studies

DEPARTMENT APPROVAL:

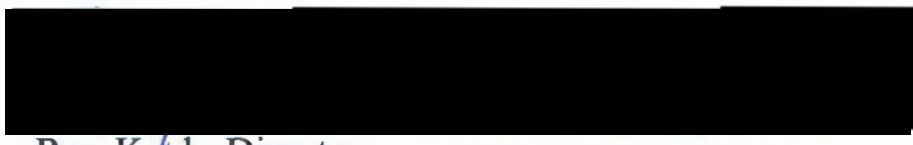

Roy Koch, Director

Environmental Sciences and

Resources Program 


\section{ABSTRACT}

An abstract of the thesis of Bruce Michael Barbarasch for the Master of Science in Environmental Sciences and Resources presented May 4, 2005.

Title: Effects of surrounding land use on plant species composition in urban forest fragments.

As human development occurs in forested areas, forests become fragmented into small islands in a matrix of urban land uses. This study examined the effect of surrounding urban land uses on the native and exotic plant species found on the edges of forest fragments in the Portland, OR metropolitan region.

A total of twenty four forest edges in three land use categories (field, residential, road) were used in the study. Edges were sampled for cover and richness using line intercept transects, run perpendicular to the forest edge. Measures of canopy cover, slope, aspect, edge age, and surrounding land use were made. Analyses of variance and covariance tests were used to examine the effect of variables and to determine if there were significant differences between land use categories and distribution of plants within transects.

It was found that road edges had significantly higher native cover than field or residential edges which were statistically the same. Three exotic species (English ivy, Himalaya blackberry, and non-native cherry) accounted for nearly $75 \%$ of the exotic 
cover. As road edges aged, native species richness increased. However, native richness decreased on field and residential edges over time. Exotic richness increased at all sites over time. Increasing interior canopy cover in residential and road edges led to a rise in exotic cover and richness, suggesting an increase in shade tolerant exotic plants.

Land managers should be aware that surrounding land uses can impact forest communities: the results of this study show that while roads may have detrimental effects on native plant communities, other urban land uses may have greater negative impacts. 


\title{
EFFECTS OF SURROUNDING LAND USE
}

ON PLANT SPECIES COMPOSITION

IN URBAN FOREST FRAGMENTS

\author{
by \\ BRUCE MICHAEL BARBARASCH
}

A thesis submitted in partial fulfillment of the requirements for the degree of

\section{MASTER OF SCIENCE \\ in \\ ENVIRONMENTAL SCIENCES AND RESOURCES}

Portland State University

2005 


\section{ACKNOWLEDGEMENTS}

This thesis would not have been possible without the support of many people who helped me out in so many ways.

My deepest gratitude goes to Kate Haas, my wife. Over the four years it took to complete this degree, she patiently listened to my complaints, shared my small triumphs, and despite her disinclination for scientific writing, provided a lot of much needed editing. While I stomped about in the woods or stayed at school late into the night, Kate cared for our growing family, cooked delicious food, and generally kept things together. Kate's parents, also known as the United States Baby Corps, were huge sanity savers not only for me, but for Kate as well. Without them, the birth of our second child midway through my studies certainly would have been the end!

I also owe thanks to the many people who came out in the forest and helped to work out the methodology, collected data, and lent moral support. Mitch Cruzan was a great mentor who always seemed to find the time to answer my endless stream of questions. I am grateful for his efforts and his SAS skills. Joe Maser and Roy Koch provided much need feedback and encouragement throughout my research. Field assistants, Moira Kerns, Elisa Payne, and Jennifer Dolan were exceptionally helpful during my first summer of data collection. Lisa Karst deserves special thanks for her assistance with plant identification. The Nature in the Neighborhood PSU Capstone students did an amazing job with data collection and number crunching. They put in countless hours and most went well beyond the call of duty. 
Finally, I wish to thank the land managers and agencies who allowed me to conduct research on their properties. 


\section{TABLE OF CONTENTS}

Acknowledgements

List of Tables

List of Figures

V

Introduction

Study description

14

Methods

Results

Discussion

48

Conclusion

Literature Cited

57

Appendix A. Species lists recorded at each site. 


\section{LIST OF TABLES}

Table 1. List of independent variables recorded at all sites.

Table 2. Analyses of variance or covariance for effects of abiotic factors on native cover.

Table 3. Analyses of variance or covariance for effects of abiotic factors on native richness.

Table 4. Analyses of variance or covariance for effects of abiotic factors on exotic richness.

Table 5. Analyses of variance or covariance for effects of abiotic factors on total richness. 


\section{LIST OF FIGURES}

Figure 1. Structure of forest edge vegetation 3

$\begin{array}{lll}\text { Figure 2. Map of study sites. } & 15\end{array}$

$\begin{array}{lll}\text { Figure 3. Example of sampling methodology } & 18\end{array}$

Figure 4. Dominance of native plants as a percentage of area covered 26 in all sites.

Figure 5. Dominance of exotic plants as a percentage of area covered in all sites.

Figure 6. Percent native cover by edge type.

Figure 7. Percent native cover by segment for all edge types. 30

Figure 8. Relationship of native cover to edge canopy by edge type. 31

Figure 9. Percent native cover versus interior canopy by edge type. 32

Figure 10. Mean native richness versus edge age for field, residential, 34 and road edges.

Figure 11. Mean native richness versus mean edge canopy cover for field, residential, and road edges.

Figure 12. Mean native richness versus mean interior canopy cover for field, residential, and road edges.

Figure 13. Mean exotic richness for road, residential, and field edges.

Figure 14. Exotic richness by $10 \mathrm{~m}$ segment for all sites.

Figure 15. Relationship between exotic richness and edge age for all sites.

Figure 16. Exotic richness versus interior canopy cover for field, residential, and road edges. 
Figure 17. Mean species richness by edge type.

Figure 18. Mean species richness per segment for all sites.

Figure 19. Mean species richness versus edge age for field, residential, 45 and road edges.

Figure 20. Relationship between total species richness and edge canopy 46 cover for all sites.

Figure 21. Relationship between total species richness and interior canopy cover for all sites. 


\section{Introduction}

E.O. Wilson (in Simberloff 1997) writes that, "On a global basis... the two great destroyers of biodiversity are first, habitat destruction and, second, invasion by exotic species." This is a view confirmed by other researchers, including Forman (1995), who said that anthropocentric land transformation and disturbance are the most significant agents of change in terrestrial ecosystems.

As human settlement advances on a forested region, the area, perimeter, and average minimum dimension in forest patches all decline (Curtis 1956, Dill and Otte 1971, Vogelmann 1995). This leads to an increase in forest fragmentation, the process in which large areas of habitat such as a forest are broken into smaller, more widely spaced units (Gutzwiller 2002).

Using remote sensing and geographic information systems, Vogelmann (1995) assessed the effects of human population growth on forest fragmentation in Southern New Hampshire and northeastern New England. He found that forest fragmentation increased with increasing population density up to about 200 people per square kilometer. Vogelmann postulated that this type of fragmentation was occurring over large portions of the east coast.

Similar patterns of fragmentation are seen in the Portland, Oregon, metropolitan region which has experienced a large amount of population growth as well as an expansion of its Urban Growth Boundary (DLCD 1992) by 3,500 acres in 1998 and 18,638 acres in 2002 (Metro 2003). This acreage consisted of both agricultural and forested land. Between 1990 and 2000, the Portland-Vancouver 
metro area had a net inflow of 400,000 people, a $34 \%$ increase in population (U.S. Census $1990 \& 2000)$.

As this type of human development occurs, forest fragments are often left behind as parks, undeveloped lands, or habitat reserves within a matrix of urban land uses. A number of physical and biological influences have been shown to affect fragments (Bastin and Thomas 1999, Burke and Nol 1998, Gregg et al 2003, Young and Mitchell 1994, Honnay et al 1999 b). However, most studies assume that adjacent land use, except for establishing an edge, has no effect on a forest fragment. The neutrality of adjacent land use is uncertain, though, since the effects of most land uses on forest edges have not been documented. In the pages below, I will discuss some of the key research on fragmentation (which includes edge structure, disturbance, exotic species, abiotic effects, island effects and ecological theory). Then I will introduce how my study which examines the effect of adjacent land use on forest fragments will attempt to fill an important gap in the literature.

There is little consensus on the exact definition of edge (Murcia 1995), but a working definition might be, "an abrupt change or transition zone between a forest and an adjacent habitat." Edges are often very distinct in urban situations. Human-made items such as sidewalks, fences, roads, or mowed grass create straight edges bordering canopy-height trees and understory vegetation. The significance of the increasing length of edges is the influence it has on the environmental conditions within the remaining forest patches. 
The physical nature of the edge itself can affect changes that occur toward the interior of the forest and varies depending on the age and structure of the forest. The age of a patch has implications for the number of species, the types of plants that might be dominant, and the structure of the edges (Bastin and Thomas 1999). Forman (1995) describes edges as a canopy level of trees that are flanked by a veil (a thin curtain of vegetation) connecting to the mantel (a dense layer of shrubs and/or small trees) and an outermost layer of perennial herbs. These parts may vary in location depending on the type of edge or the time since disturbance (Figure 1).

a.

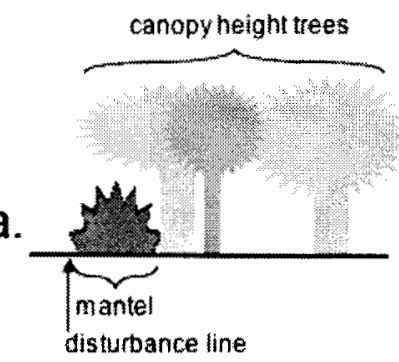

b.

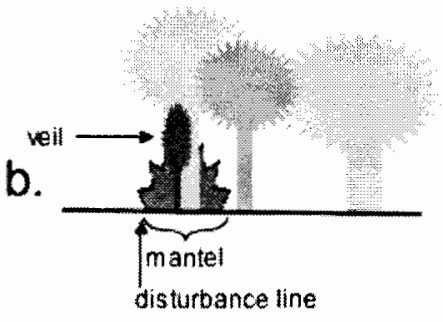

c.

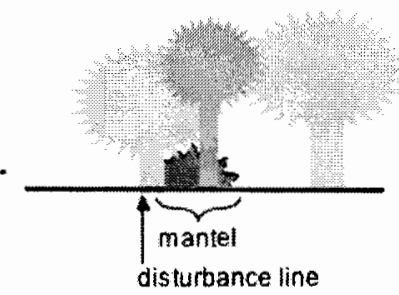

Figure 1. Structure of forest edge vegetation (after Forman 1995). As the disturbance line gets closer to canopy level trees (a), the mantel recedes further inside the forest (c).

Edges are often characterized by disturbance. In Western Oregon and Washington, natural disturbances in upland forests include large mammal activity, blow-down, fire, disease outbreaks, and insect infestations (Perry 1994). Human disturbances include logging, surrounding land-use change (Godefroid and Koedam 2003), and recreation (Brookes 1996). Although disturbance is a normal and 
important feature of most ecosystems, natural disturbance regimes such as fire are generally absent from nature reserves (Hobbs and Huenneke 1992).

Disturbance may also influence species diversity, with the highest levels of diversity found in areas with moderate levels of disturbance, a relationship that Connell (1978) called the intermediate disturbance hypothesis. In a disturbed area, space becomes available for a variety of species with different needs. In areas with little disturbance, competitive exclusion reduces species richness over time. This relationship has been observed in a number of studies in both rural and urban areas. Deutschewitz, et al. (2003) found that species richness of native and exotic plants increases with moderate levels of natural and anthropogenic disturbances across a gradient of urban and rural forest fragments. At a central California habitat reserve, the highest number of introduced species were found around areas of human disturbance such as roads and buildings, not in habitats that were either relatively stable such as a chaparral or in grasslands that had high levels of disturbance due to small mammals (Knops et al. 1995). In areas of soil disturbance along gravel roads in forested areas, and on exposed stream banks subjected to flooding or debris flows, Parendes and Jones (2000) observed there was a higher frequency of exotic plants than in undisturbed forests nearby. The extent of exotic plant invasion in the study was influenced by the intensity of disturbance and light levels. Although these studies cited the potential for invasion of exotic species with disturbance, some shade intolerant native species such as Douglas fir or red alder also need disturbance and are less likely to recruit under stable conditions (Franklin and Dyrness 1973). 
It appears that some disturbances which happen in or outside a forest edge may impact the edge or the habitat interior. Research by Gelbard and Belnap (2003) in semiarid grassland, shrubland, and woodlands showed that paved roads had up to three times the number of exotic species found on four-wheel-drive dirt roads. They were not surprised by this result because, "road improvement serves as an indicator of the frequency of exotic plant seed introductions by vehicles and roadfill." Other studies have demonstrated that viable seeds and pathogens can be transported by mud on shoes or vehicles (Lonsdale and Lane 1994, Jules et al. 2002). None of these studies were conducted in urban areas, where vehicles are less likely to go off-road or to be exposed to sources of exotic seeds, nor were they conducted in habitats similar to the coniferous forests of the Pacific Northwest.

In addition to roads, other human activities can also affect vegetation communities. For example, human activity off-trail has also been shown to reduce sapling density in a forested Japanese park (Bhuju and Ohsawa 1997). Powerline corridors may also affect vegetation in forest edges. Increased reproduction, higher stem densities, and more shade intolerant species can be found as a possible result of increased light in these areas; these effects are estimated to extend $10-15 \mathrm{~m}$ into forests (Luken et al. 1991). Luken's study compared the characteristics of the edge to the forest interior, but failed to compare it to other natural or anthropocentric edge conditions. 
Edge effects include both biotic influences such as the spread of invasive plants and abiotic influences, such as changes in temperature, light levels, and air movement inside forests. These influences will be further discussed below.

A number of other researchers have studied the influence of biotic edge effects, principally the spread of invasive and exotic plant species. Again, the structure of the forest edge may play an important role in seed dispersal. Meekins and McCarthy (2001) found that germination, growth, and survival of exotic forest herbs were significantly higher in edge plots than interior plots due to light availability, but that litter disturbance did not play a role in the germination rate of these herbs. Some studies have noted disturbance as a key factor in the establishment of exotic species, either because non-forest seeds could disperse further into fragments whose edges had been cleared of low growing vegetation (Cadenasso and Pickett 2001) or because the "dense wall of bordering vegetation" reduced light and wind that could bring exotic seeds into the forest (Brothers and Spingarn 1992).

Opinions about the impact of exotic species vary. Although Burke and Nol (1998) observed exotic plant species in the interior of patches, they did not consider them significant because they occupied less than 3 percent of ground cover more than 20 meters inside the forest. Hutchinson and Vankat (1997) however, found that exotic honeysuckle from a nearby town had a deleterious effect on native species in rural forest fragments well within the interior. They also showed that the longer the fragment had been invaded, the greater the percent cover of the honeysuckle. 
In the Pacific Northwest two invasive ornamentals are considered threats to forest health. Both English ivy, Hedera helix, and English holly, Ilex aquifolium, are listed as noxious weeds by the Oregon Department of Agriculture (2003) because, "they disrupt natural ecosystems by displacing native species; reduce natural diversity by replacing native communities with invasive monotypic weed stands; impact wildlife by altering habitat and watersheds." The existence of groups such as the No Ivy League, whose sole purpose is to remove $H$. helix from Portland's natural areas, indicates the intensity of the exotic plant threat.

In addition to biotic edge effects, many researchers have looked at the effect abiotic factors have on forest interiors. Studying edge effects in cool, moist New Zealand forests, Young and Mitchell (1994) found that light, air temperature, and vapor pressure had impacts reaching a distance of $50 \mathrm{~m}$ into the forest, regardless of the size of the fragment. They concluded that because of this effect, fragments under 9 hectares would be dominated by edge effects. Other researchers found that the microclimatic effects were limited to 5 meters (Burke and Nol 1998).

Weathers et al. (2001) studied the throughfall of nutrients at forest edges and recorded sulfur, nitrogen, and calcium concentrations higher in edges than they were in the interior. Since these are important nutrients whose absence may limit plant growth, they could have an important influence on the forest edge. Furthermore, these effects could be intensified in urban areas since human activities can affect the concentrations of chemicals in the air (Gregg et al. 2003). 
In addition to the edge effects themselves, plant species composition has been correlated with the size and shape of forest fragment. Many scientists have shown with species-area curves that larger patches (or islands) up to a threshold size are likely to contain more species (Diamond and Mayr 1976, MacArthur and Wilson 1967). Beyond this size species diversity grows slowly. The shape of the patch influences the amount of edge area in relation to the amount of interior area. O'Neil (2000) found that native and exotic plant species diversity was related to riparian zone perimeter-area ratios in NW Oregon. Interior habitat usually serves a set of plants with more specific ecological needs as opposed to edge habitat, which often allows for a wider variety of generalist plants.

In The Theory of Island Biogeography, MacArthur and Wilson (1967) state that the number of species on an island is determined by the amount of immigration and extinction. That amount is theoretically balanced because species that are going extinct are replaced by other species. In forest patches or islands in an urban matrix, immigrating plant species may not be natives, since most homes and business are landscaped with exotic materials. A fragment's isolation from other islands with native seed sources may contribute to this situation (Honnay et al. 1999b). This raises the question: Do exotic plant species replace native plants over time?

Discussions of true island biogeography have led to practical applications in nature reserves, which are habitat areas surrounded by, 'an 'ocean' of habitat made unsuitable, and therefore hostile, by man" (Begon et al. 1990). The debate about best to arrange for reserves focuses around variations on the idea of SLOSS: a Single Large 
or Several Small Reserves. Researchers have tried to decide which type of reserve best protects populations and balances the risk of extinction due to stochastic events against the impacts of edge effects. Another component deals with the loss or "relaxation" of species from a newly formed island. An island may initially contain more species than it is capable of sustaining without access to the resources of adjacent forests. A loss of species will occur until the fragment reaches a balanced level of species richness (Pysek et al. 2002, Quinn and Harrison 1988, Murphy and Wilcox 1986.)

Because in most cases land managers must deal with existing reserves (and do not get to plan habitat reserves prior to development), theoretical debates about SLOSS and island biogeography are somewhat irrelevant to their missions (Saunders et al. 1991). Saunders argues that managers need to maintain the diversity of species in their reserves and must learn to manage some of the external influences on reserves, with the given resources available. He stresses that more studies must examine the influence of isolation on habitat fragments. Isolation alone is important, but the land use matrix must also be taken into account.

While many studies have examined forest fragments in an agricultural matrix (Cadenasso and Pickett 2001, Meekins and McCarthy 2001, Hutchinson and Vankat 1997), much less has been done in an urban matrix. Bastin and Thomas (1999), examined the effects of 22 plant species in a variety of habitats ranging from open water to remnant forest in the United Kingdom. They found that the incidence of these species increased with site age, area, and the similarity of adjacent habitats 
(which included urban land uses such as parking lots and residential gardens).

Unfortunately, because of the study's broad array of habitats, it is difficult to apply the findings to a particular habitat. The study also fails to conclude if adjacent land uses such as parking lots had negative impacts on the existing habitat.

Another urban study looked at the relationship between a suite of forest plant species and fragment characteristics such as patch area, habitat diversity, and isolation from similar habitats (Honnay et al. 1999b). It found that the more isolated a patch was, the lower its richness. Larger fragments were found to be critical for species richness since they were better able to handle the disturbance on their edges which led to increased invasions of exotic plants.

Other important investigations of edge effects, recolonization, and extinction vulnerability have been done in coastal sage scrub in an urban matrix by Soule et al. (1992) and Bolger et al. (1997). They found a decrease in the number of plants species since the time the fragment was isolated. This habitat is very different than the forests of Western Oregon and is of limited utility to forest managers.

Among the few studies of the Pacific Northwest, two that were done in urban areas, are of particular interest. The first study, by Hennings and Edge (2003) examined bird populations and "community measures" of richness, nativity and abundance, as well as forest cover in urban riparian areas. The study also investigated the relationships between these community measures and paved road density as an indicator of urbanization. A number of significant relationships were found, but of relevance to this discussion was the findings that native bird diversity and richness 
was highest in less urbanized areas. The study suggested that increasing canopy cover near streams was, "the most valuable land management action for conserving native breeding birds."

Magee et al. (1999) evaluated the floristic condition of wetlands in urban areas of Portland, OR, and used the presence of exotic species as indicators of poor ecological health. Part of the study compared the number of exotics with the adjacent land use in four categories. Native species richness was comparable in each category, but the number exotics were highest in agricultural and commercial/industrial/transportation classifications.

These studies show that land use can impact plant and animal species composition and exotics in habitat fragments. However they do not address upland forests, and it is not clear whether similar trends apply to all habitat areas.

Land managers often have little say about what occurs on adjacent lands. However, knowledge of these effects could prove useful in determining management priorities, long term maintenance, and in gaining a better understanding of forest fragment dynamics. A study that links edge effects to types of surrounding land use would be useful to land managers who do not have the time or resources to study their reserves intensively.

Urban nature reserves containing forest fragments are important because they serve as pools of biodiversity and refuge for native wildlife, as well as providing a source of enjoyment for humans. Urban wildlife depends on native vegetation for food and shelter, and interior forest species are especially dependent on intact forests 
(Hagar 1999, Brand 2001). Urban forests can also provide habitat for rare species such as the pileated woodpecker, Dryocopus pileatus, or those with limited dispersal abilities such as the Northern red legged frog, Rana aurora. Both are listed as sensitive species by the Oregon Department of Fish and Wildlife (1997).

Woodpeckers and frogs are dependent on interior forest conditions for all or a large part of their life cycle and can be found in forest fragments in the Portland, Oregon, metropolitan region (Kyle Spinks, pers. comm.).

In Oregon many urban forested lands are protected under the State's regulation to conserve natural resources and open spaces which is known as Goal 5 (OAR 660015-0000(5)). It requires that jurisdictions create plans to, "provide for the preservation of significant natural areas..." A better understanding of fragmented plant communities in urbanizing areas could be critical to the long term maintenance and management of these natural areas.

In summary, we now know that edges are important transition zones and areas of disturbance. Disturbance is a challenge to land managers because it is a way to increase diversity, but also can introduce exotic plants which are major threats to native communities (Heywood 1989). Unfortunately, there is a paucity of published studies of urban forests in the United States and nothing about the Pacific Northwest; this leaves urban land managers working on Goal 5 issues with only anecdotal information about local forest processes. Furthermore, existing studies of edge effects make the assumption that adjacent land uses all have equivalent effects on forest edges. 
This study focused on the intersection of ecological theory and on-the groundmanagement of urban forests., and increases the amount of information available to land managers. It examined the effects of roads, fields, and residential land uses on native and exotic plant richness and cover in upland forest fragment edges. The study addressed some of the key questions facing urban forest managers in the Pacific Northwest:

- Does the use of land adjacent to the forest fragment affect the species composition in the forest edge? Roads have been shown to be vectors of seeds and a source of disturbance to adjacent habitats. Is this true in the urban environment and if so, are there other land uses that have similar effects? The null hypothesis was that all adjacent land uses would have the same effect on species composition. The alternative hypothesis was that adjacent land uses would have differing effects.

- Does the age of the edge affect the species composition in the forest edge? Do exotic species replace natives over time? The null hypothesis was that age would not affect the species composition in the forest edge. The alternative hypothesis was that age would affect the species composition in the forest edge.

- Does forest canopy density impact species composition near a forest edge? The null hypothesis was that canopy density would not affect the species composition in the forest edge. The alternative hypothesis was that canopy density would affect the species composition in the forest edge. 


\section{Study Description}

The primary objective of this study was to examine the plant species composition found in urban forest fragment edges in relation to the adjacent land use: fields, residential areas, or roads. These land use categories are defined as follows:

- Field. Land that is vacant but unpaved. Uncut, grassy fields or mowed grass falls in this category. This land use has no paving and little to no vehicle access. Power line corridors exemplify this category.

- Residential. These sites consist of single family residential houses. They have minimal pavement and landscaped areas abut forest boundaries.

- Road. This category is typified by large areas of pavement, frequent vehicle activity, and little to no landscaping.

The study's focus was on native and exotic plant cover and richness. It was assumed that healthy forests would have high percentages of native cover. The location of different plants along the edge gradient was also of interest. The effects of slope, aspect, soil type, edge age, and canopy cover on richness and cover were analyzed.

Throughout this document, the term "park" refers to a specific managed natural area. "Site" or "study site" refers to an area within a park that contains forest areas that were used in this study. These parks were in the Lower Willamette River Basin within the Urban Growth Boundary of the Portland, Oregon metropolitan area (Figure 2). The parks were largely dominated by upland forest, but wetland, riparian, and meadow habitats were often contained within park boundaries. Parks ranged in 
size between 6 and 650 acres. Human visitation of these parks varied; some were simply habitat reserves while others contained narrow dirt trails designed for foot traffic.

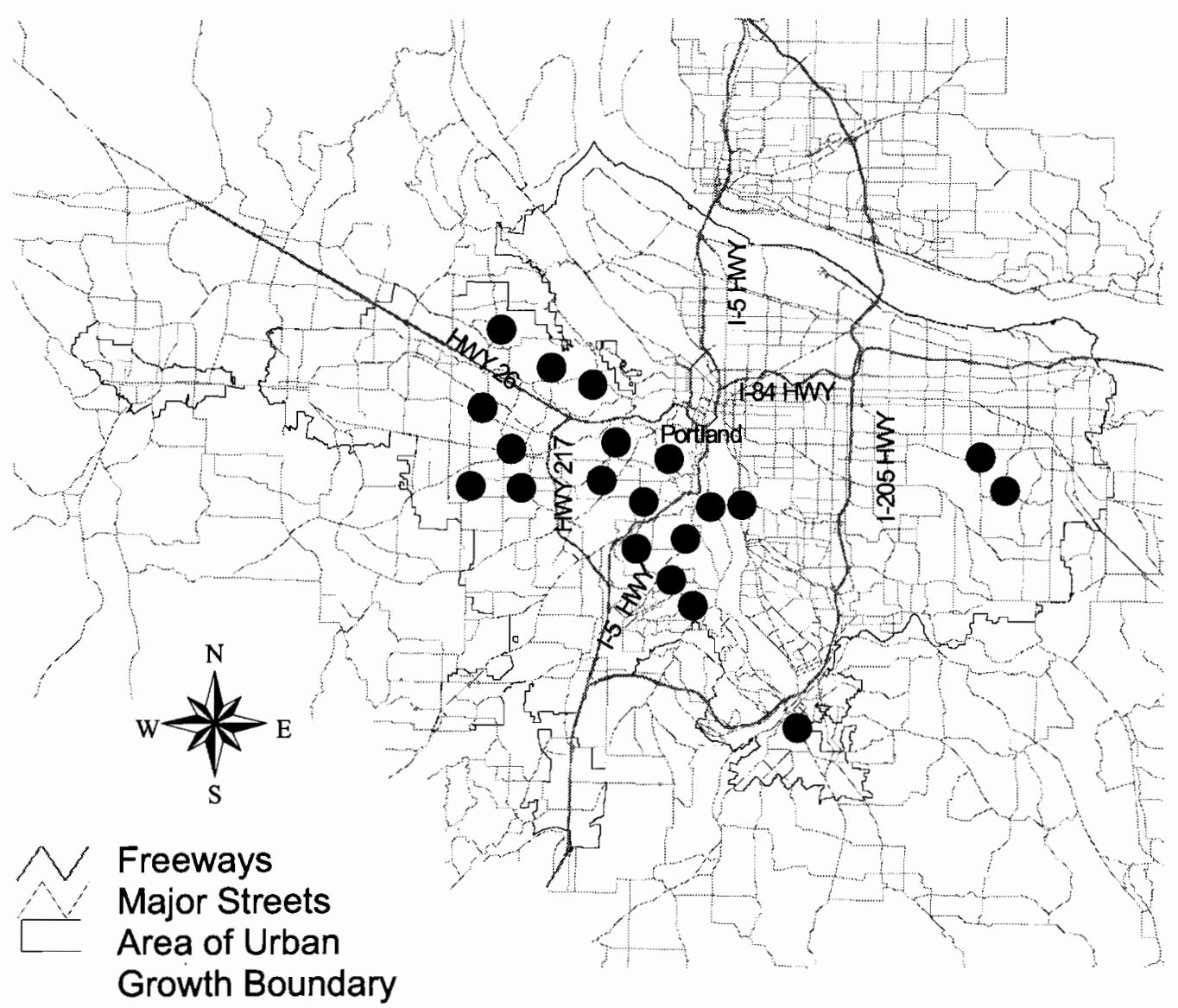

Figure 2. Map of the Portland, Oregon metropolitan region's area within the

Urban Growth Boundary. Dots indicate study sites.

Study sites were in forested habitats that fell into the National Vegetation Classification System category, mixed evergreen-deciduous forest (NVCS 2003). For purposes of simplification, this category is called "upland forest" in this paper. This habitat was chosen to minimize the variability that could arise when comparing 
different forested habitats such as riparian areas. Upland forests are also a type of forest that are commonly surrounded by human settlements. These forests are dominated by conifers like Douglas Fir, Psuedotsuga menziesii, and Western red cedar, Thuja plicata. Other species such as big leaf maple, Acer macrophyllum, red alder, Alnus rubra, and Oregon white oak, Quercus garryana, may also be prominent. The understory typically contains shrubs including vine maple, Acer circinatum, Oregon grape, Mahonia sp., and beaked hazelnut, Corylus cornuta. Common herbs include fringecup, Tellima grandiflora, and inside-out flower, Vancouveria hexandra.

Portland has a mild climate with mean annual high temperatures of approximately 26.7 degrees $\mathrm{C}$ and mean annual lows near 0.9 degrees $\mathrm{C}$. The region gets approximately $92 \mathrm{~cm}$ of rain per year, with about $90 \%$ of it falling between October and May (Rockey 2004). Persistent light rain is common throughout the year, although the summer months (June, July, August) may be dry. This type of climate fosters the dominance of conifers in many plant communities because they can continue growing through much of the cool rainy winter months, while deciduous trees are only able to photosynthesize during a much shorter portion of the year (Perry 1994).

Soils in the study area were dominated by loams. A loamy soil is one which is made up of relatively equal amounts of clay, silt, and sand. Many of these soils were formed from volcanic ash and sediment from weathered basalt or andesite (Green 1983). 


\section{Methods}

Parks with specific surrounding land use conditions within $50 \mathrm{~m}$ of their edges were selected. Twenty four sites in twenty two parks were studied. There were not enough sites of sufficient size to be chosen in a random fashion, however sampling within each was done randomly. This study was conducted over two years with the field work done between mid-June and mid-August of 2004 and 2005. This time period was chosen because it spanned the peak of the growing season when most plants were fully "leafed out" and actively growing. Efforts were made to ensure that annual or perennial herbaceous plants were identified, even if they were not entirely green. It is likely that some early blooming herbs were not fully represented during the sampling period.

In order to measure plant species composition, line intercept transects were run on edge locations at each site, using methodology based on Bonham (1989). The line intercept method was chosen because it is able to show changes in plant species composition along the edge gradient, gives presence or absence information, and allows an estimation of percent cover of different species. This method is also less prone to observer bias than visual estimates in quadrats (Elzinga et al. 2001). This was important since student research assistants collected large portions of the data.

At each site, a set of three, 30 meter transects were run perpendicular to the edge, towards the interior. During preliminary field studies, three, 50 meter line intercept transects were run perpendicular to the edge at each site. Histograms were plotted which showed the number of new species found along the transect. At 30 
meters the number of new species found dramatically decreased or stopped. Since no new information was being obtained beyond this point, it was decided that the transect length would be 30 meters.

To avoid measuring edge effects from two directions, transects began at least $30 \mathrm{~m}$ away from the nearest corner or area of overlap (Figure 3 ), after methods by Young and Mitchell (1994). Edge transects started at the nearest human-created edge such as a sidewalk, street, mowed grass line, fence, or ornamental planting. Where ambiguity existed, the transect started at the drip-line of the nearest canopy height tree.

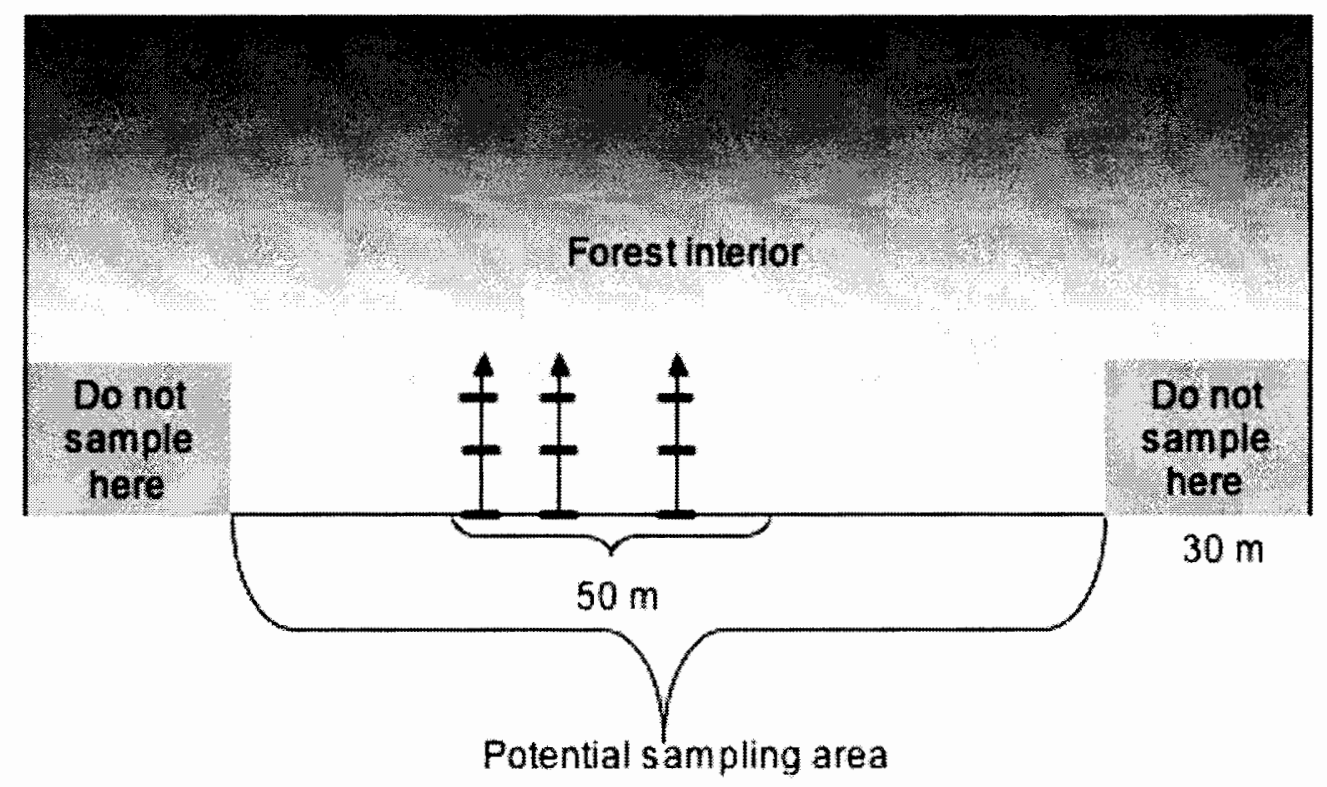

Figure 3. Example of sampling methodology at a theoretical park with homogenous forest habitat. Arrows indicate potential transect locations. Bars show transect segments used in data analysis. Note: parks can be any shape providing they meet size requirements. 
Transect starting points were selected using a random number table corresponding to a 50 meter section of the forest that was deemed to be representative of the larger fragment. Transect locations that fell on areas that were visually different from the surrounding forest (creek channels, springs, or recent tree falls) or had obvious disturbances (human trails, restoration areas, or recent fires) were discarded and replaced with another randomly selected location. Transects were run at least 5 meters apart from each other.

The minimum study site dimension was $110 \mathrm{~m}$ by $70 \mathrm{~m}$. At minimal sized sites, transects began on the longest edge. If the site was large enough, multiple edges were sampled, but no more than one set of transects was conducted along any edge type. For example if a site had two "usable" road edges and two residential edges, a maximum of one road and one residential edge could be sampled.

Only vascular plants were identified and used to calculate richness and cover measures: grasses, mosses, and lichen were excluded. Plants were identified to the species level. If a plant could not be identified in the field, a sample was taken, assigned a code number, and identified later. The nativity of a plant was determined using Hitchcock (1973), Pojar (1994), Hogan (1988),or the Portland State University herbarium. Native plants are defined as those that were naturally occurring in this region prior to the arrival of European settlers. Exotic plants are non-native plants that include ornamental and agricultural plants. Plants considered "pests" such as horsetail, Equisetum sp., which are natives are not considered exotic. For purposes of this study, total species richness is the sum of both native and exotic species. Native 
or exotic richness is the total number of each respective species. Canopy, shrub, and herbaceous layers of each forest were measured for cover and richness. Tree, shrub and herb layers were combined to calculate cover measures.

Plants were measured to the nearest centimeter. Plants with a base and radiating branches were recorded from living tip to living tip, regardless of gaps. For example, a sword fern, Polystichum munitum, may stretch $0.98 \mathrm{~m}$ from frond tip to frond tip, but the leaflets may not cover that entire distance along the tape measure. Since the plant "occupies" the $0.98 \mathrm{~m}$, that is the length that was recorded (Brower 1998). Vine-like plants such as trailing blackberry, Rubus ursinus, were recorded only where they crossed the transect line. If there was a gap of less than $2 \mathrm{~cm}$ between plants of the same species, they were measured continuously. If there was more than a $2 \mathrm{~cm}$ gap, the plants were recorded separately. The length of cover measured could easily be longer than the distance of the transect, since multiple layers of plants overlap each other. The length each plant species covered was used to calculate measures of exotic cover and native cover. Native cover was calculated by dividing the length covered by all native species with the total length covered by all species. This provided a percent native cover figure. Exotic cover is calculated by subtracting the percent native cover from $100 \%$. Cover was considered a measure of plant dominance (Brower 1998).

A spherical crown densiometer was used to measure canopy closure/cover at the zero mark of the transect (beginning of the transect) and will be referred to as edge canopy cover. Another densiometer measurement was taken at the 30 meter mark, 
which represented the end of each transect and will be referred to as the interior canopy cover. Densiometer readings were made by following manufacturer's instructions (Lemmon). Canopy cover was considered a surrogate for light penetration to the forest floor (Englund 2000). These measurements were made as an effort to observe variables that might affect the plant species composition at each site.

Soil types at each site were determined using Soil (National Resources) Conservation Service, Soil Survey maps (Gerig 1985, Green 1982, 1983).

Slope and aspect were determined on site. Slope was visually estimated by field assistants and recorded in categories rather than as a continuous measurement. The categories were as follows: Flat to 9.99 degrees, 10 to 24.99 degrees, 25 to 45 degrees. No sites steeper than 45 degrees were sampled because it was felt that they did not represent similar enough communities. Aspect was determined using a compass.

For residential and field sites, edge age was estimated by consulting property tax records and determining the date of development along said edge. Road site ages were determined by reviewing records of the appropriate management agency and finding the date a road was constructed or greatly expanded.

\section{Data analysis}

Data from each $30 \mathrm{~m}$ transect was divided into three $10 \mathrm{~m}$ segments for analysis (where zero represents the point between the forest edge and the surrounding 
land use): outer edge $=0$ to $9.99 \mathrm{~m}$, middle $=10$ to $19.99 \mathrm{~m}$, and interior $=20$ to 30 m. This division allowed a closer examination of heterogeneity within each transect.

Prior to statistical analysis, a sum was calculated for each of the dependent variables for each transect at each site, then a mean was calculated for each site as a whole. For example, a native species richness was calculated along each transect, then a mean was made for each of the site's three transects. Dependent variables consisted of: total richness, exotic richness, native richness, native area, and total area. Means were calculated for the continuous independent variables of edge and interior canopy cover at each site: edge age was not calculated as it was the same for each transect at a site. These means were used as data for the statistical analysis. All other independent variables were categorical (Table 1).

Table 1. List of independent variables recorded at all sites.

\begin{tabular}{|c|c|}
\hline \multicolumn{2}{|c|}{ Independent variables } \\
\hline Categorical & Continuous \\
\hline O Edge type & - Edge canopy cover \\
\hline - Segment & - Interior canopy cover \\
\hline - Slope & $\circ$ Age of edge \\
\hline - Aspect & \\
\hline - Soil type & \\
\hline
\end{tabular}

Statistics were done using the SAS computer program on a Windows based personal computer. Data were checked with SAS's proc-univariate feature and found be approximately normally distributed. SAS's GLM (General Linear Models) Procedure was used to conduct analysis of variance and covariance on the data. The 
procedure, "uses the method of least squares to fit general linear models." (SAS Institute 1989) A general linear model can be used where there is a response variable (dependent variable) and one or more predictor variables (independent variables).

SAS was programmed to create a statistical model that "fitted" or related the predictor variables to the response variables. According to Quinn (2002), the response variable equals the model plus error. The error is a measure of uncertainty which is not explained by the model. The model makes an estimate of the true value of a parameter, then determines the error, or distance of the actual data is from it.

The GLM Procedure can do Analysis of Covariance (ANCOVA). ANCOVA was chosen because it was capable of analyzing the relationships between the study's variables which had both categorical and continuous data.

A p-value was calculated by SAS to show the probability that the results were not due to chance. For this study, if the test returned a p-value of $<0.05$ the result was deemed significant. SAS's Least Squares Means (LSM) test was used as a post-hoc test on means that had a statistically significant difference from the others.

Edge type was considered a fixed variable since the study was particularly interested in the effects of surrounding land uses, while soil, slope, aspect and canopy cover measures were considered random effects. 


\section{Results}

The results of the ANOVA and ANCOVA tests run through the GLM procedure can be found in this section. This section begins with an overview of the general vegetation and soil data, followed by the outcomes of tests of the independent variables; these are presented in the following order: native cover, native richness, exotic richness, total species richness.

Slope and aspect were random variables, and although there were statistically significant test results relating to them, the unequal distribution of their numbers makes the interpretation of these results uncertain. For example, there were eight different compass directions recorded for aspect, with between one and three sites in most directions, but one direction had eight sites. This distribution of aspect made analysis of this variable meaningless and was therefore not performed. Slope had a similar distribution and therefore it is not discussed. In addition, soil was not shown to have significant effects in preliminary statistical tests, so it was removed from final analyses.

\section{General Vegetation and Soil Data}

One hundred thirty six plant species were found in the study's 24 sites (in 19 different parks) (Appendix A). Eighty seven of the species (64\%) were native species while forty nine (36\%) were exotic. Seven native species accounted for nearly $75 \%$ of the area covered by natives (Figure 4). Dominant trees (in descending order) included bigleaf maple, Acer macrophyllum, Douglas fir, Psuedotsuga menziesii, and red alder, 
Alnus rubra. Beaked hazelnut, Corylus cornuta, sword fern, Polystichum munitum, and trailing blackberry, Rubus ursinus, dominated the shrub/herb layers.

English ivy, Hedera helix, Himalayan blackberry, Rubus armeniacus, sweet cherry, Prunus avium, Robert's geranium, Geranium robertianum, English hawthorn, Cretaegus monogyna, and English holly, Ilex aquifolium, were the exotic plants (in descending order) with the highest percent cover (Figure 5). While dominant exotic species richness was similar across edge types, the cover of English ivy on road edges was approximately half of what was recorded on field or residential edges.

Thirteen different types of soils were identified during the study. Many sites had similar soil conditions. Eleven soils were loams (nine were silt loams, one a silty clay loam, and one a gravely loam). Two sites each had Cascade urban land complex and xerochrepts and haploxerolls. 


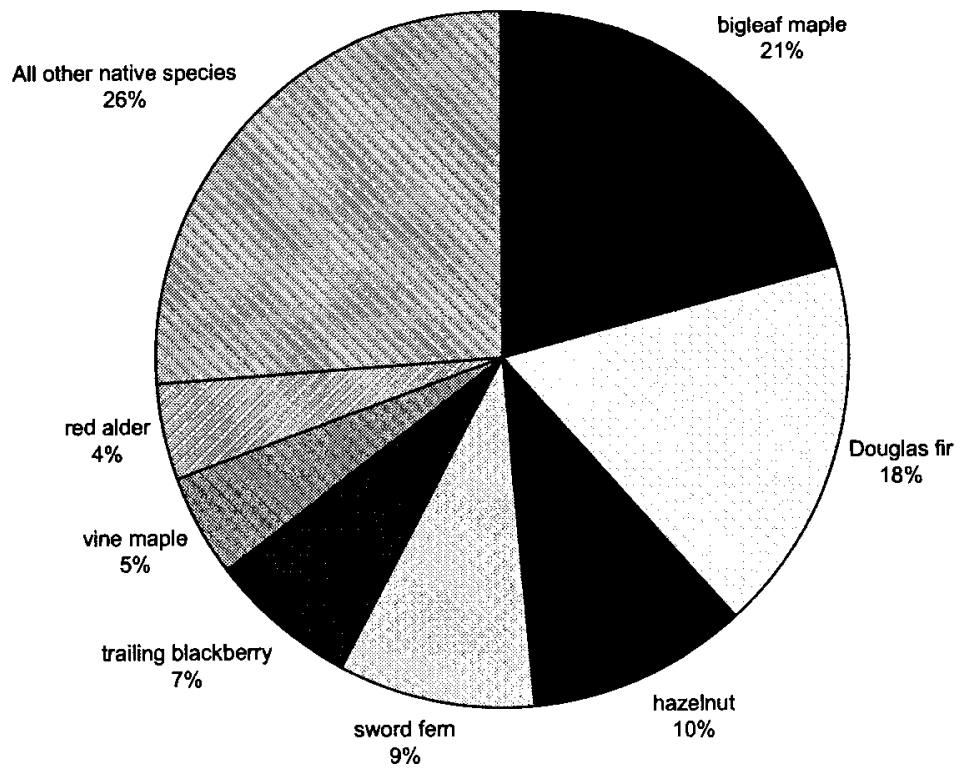

Figure 4. Dominance of native plants as a percentage of area covered in all sites. 


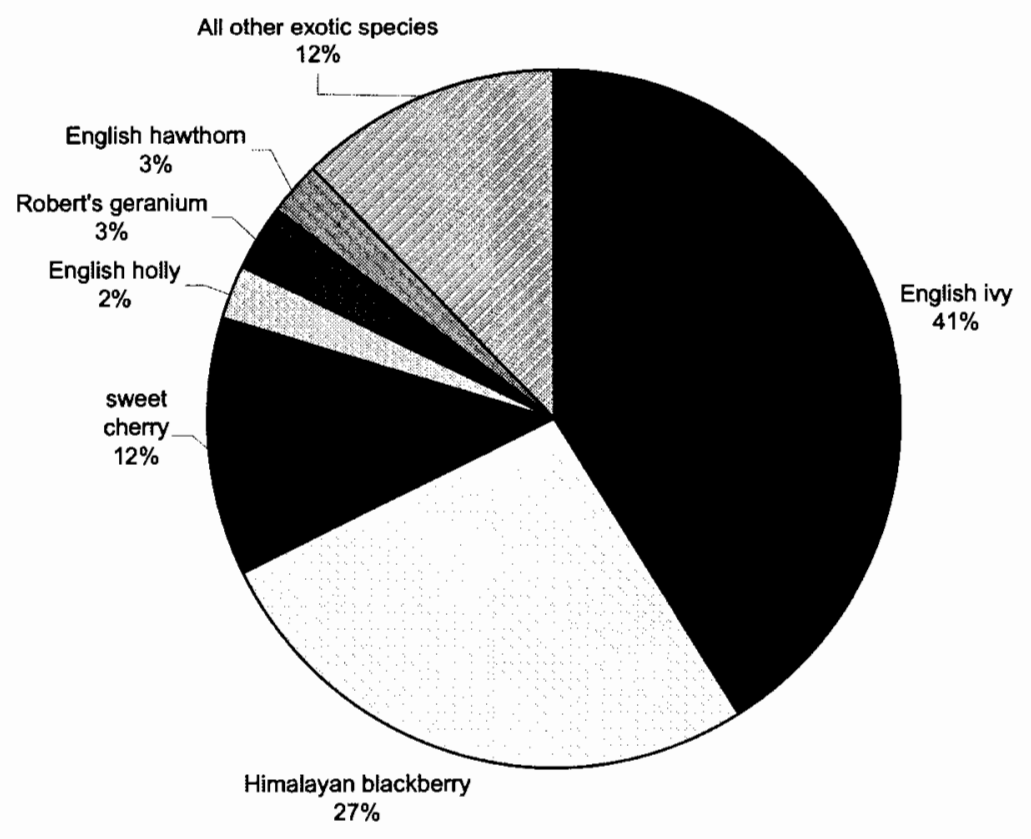

Figure 5. Dominance of exotic plants as a percentage of area covered in all sites.

\section{$\underline{\text { Native Cover }}$}

Based on ANOVA tests done through the GLM procedure, native cover was different depending on the edge type $(p=0.0182)$ (Table 2$)$. Road edges had the highest native cover $(\mathrm{p}<0.0170)$ when compared to residential or field edges. Although residential sites had slightly higher native cover than field sites, they were both statistically the same (Figure 6).

Native cover was not affected by the age of the edge in any edge type. 
Table 2. Analyses of variance or covariance for effects of abiotic factors on native cover.

\begin{tabular}{|l|l|l|l|l|l|}
\hline Source of variation & $D F$ & $\begin{array}{l}\text { Sum of } \\
\text { squares }\end{array}$ & $\begin{array}{l}\text { Mean } \\
\text { square }\end{array}$ & $\begin{array}{l}F \\
\text { value }\end{array}$ & $P>F$ \\
\hline Edge type & 2 & 406.2483 & 203.1242 & 4.10 & 0.0182 \\
\hline Segment & 2 & 337.2445 & 168.6223 & 3.40 & 0.0355 \\
\hline Edge $x$ segment & 4 & 717.5051 & 179.3762 & 3.62 & 0.0073 \\
\hline Age of all edges & 1 & 3.0769 & 3.0769 & 0.06 & 0.8036 \\
\hline Age $x$ edge type & 2 & 34.6999 & 17.3499 & 0.35 & 0.7053 \\
\hline Edge canopy cover & 1 & 266.5938 & 266.5938 & 5.38 & 0.0215 \\
\hline Interior canopy cover & 1 & 790.0677 & 790.0677 & 15.93 & $<0.0001$ \\
\hline $\begin{array}{l}\text { Edge canopy cover } \mathrm{x} \\
\text { edge type }\end{array}$ & 2 & 1062.8088 & 531.4044 & 10.71 & $<0.0001$ \\
\hline $\begin{array}{l}\text { Interior canopy cover } \mathrm{x} \\
\text { edge type }\end{array}$ & 2 & 511.5471 & 255.7735 & 5.16 & 0.0066 \\
\hline Slope & 2 & 275.5617 & 137.7808 & 2.78 & 0.0647 \\
\hline Aspect & 1 & 4.6757 & 4.6757 & 0.09 & .7592 \\
\hline Edge $\mathrm{x}$ slope & 4 & 502.1839 & 125.5459 & 2.53 & 0.0419 \\
\hline Age $\mathrm{x}$ slope & 2 & 31.8276 & 15.9138 & 0.32 & 0.7259 \\
\hline Age $\mathrm{x}$ aspect & 1 & 1.2344 & 1.2344 & 0.02 & 0.8748 \\
\hline Slope $\mathrm{x}$ aspect & 2 & 136.4762 & 68.2381 & 1.38 & 0.2552 \\
\hline
\end{tabular}




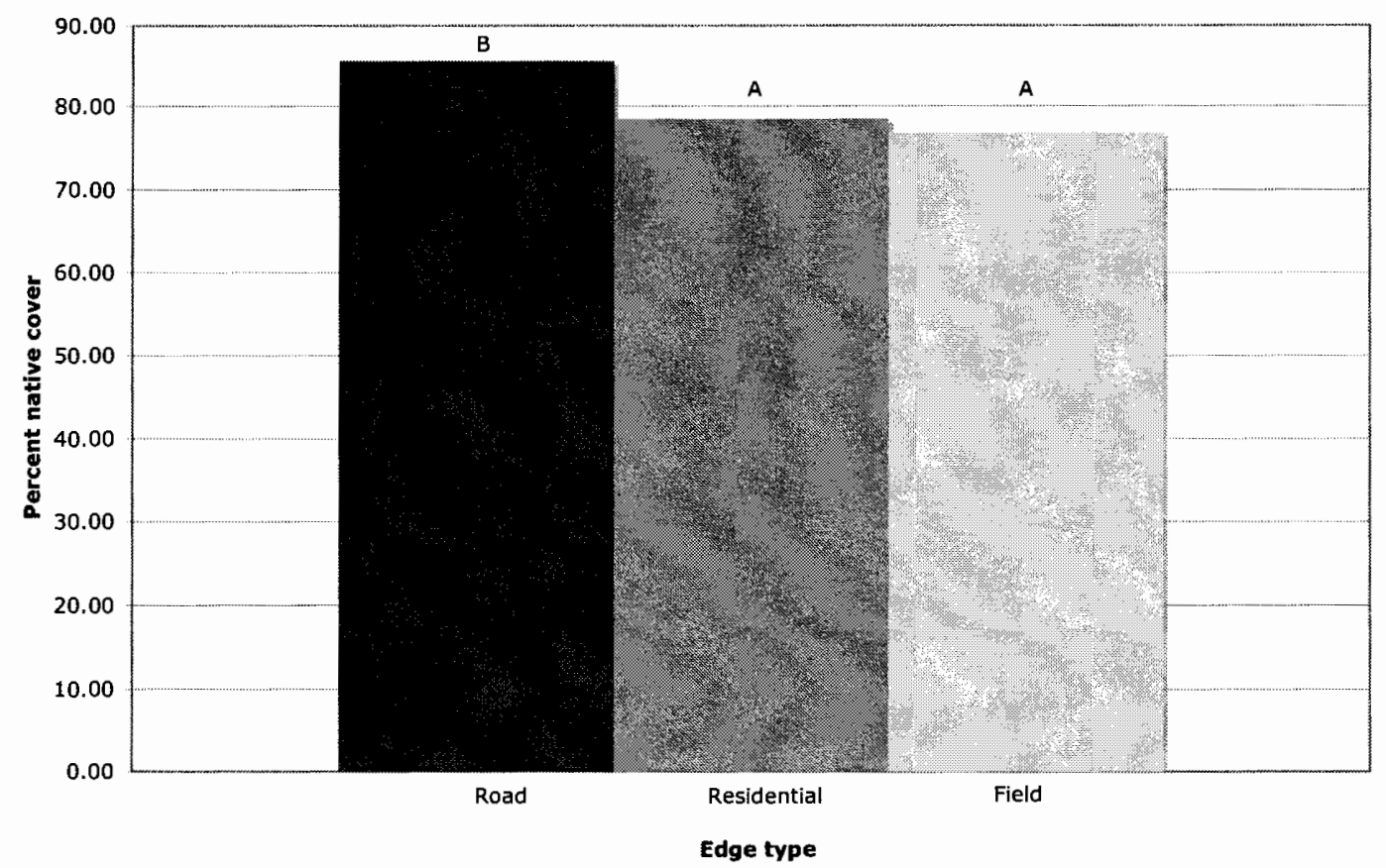

Figure 6. Percent native cover by edge type. Different letters indicate significant differences $(p<0.05)$ between edge types. Differences were determined using total native cover and transformed into percent native cover.

When examining native cover per segment for all sites, it was lowest on the outside and the same in the middle and interior segments (Figure 7). 


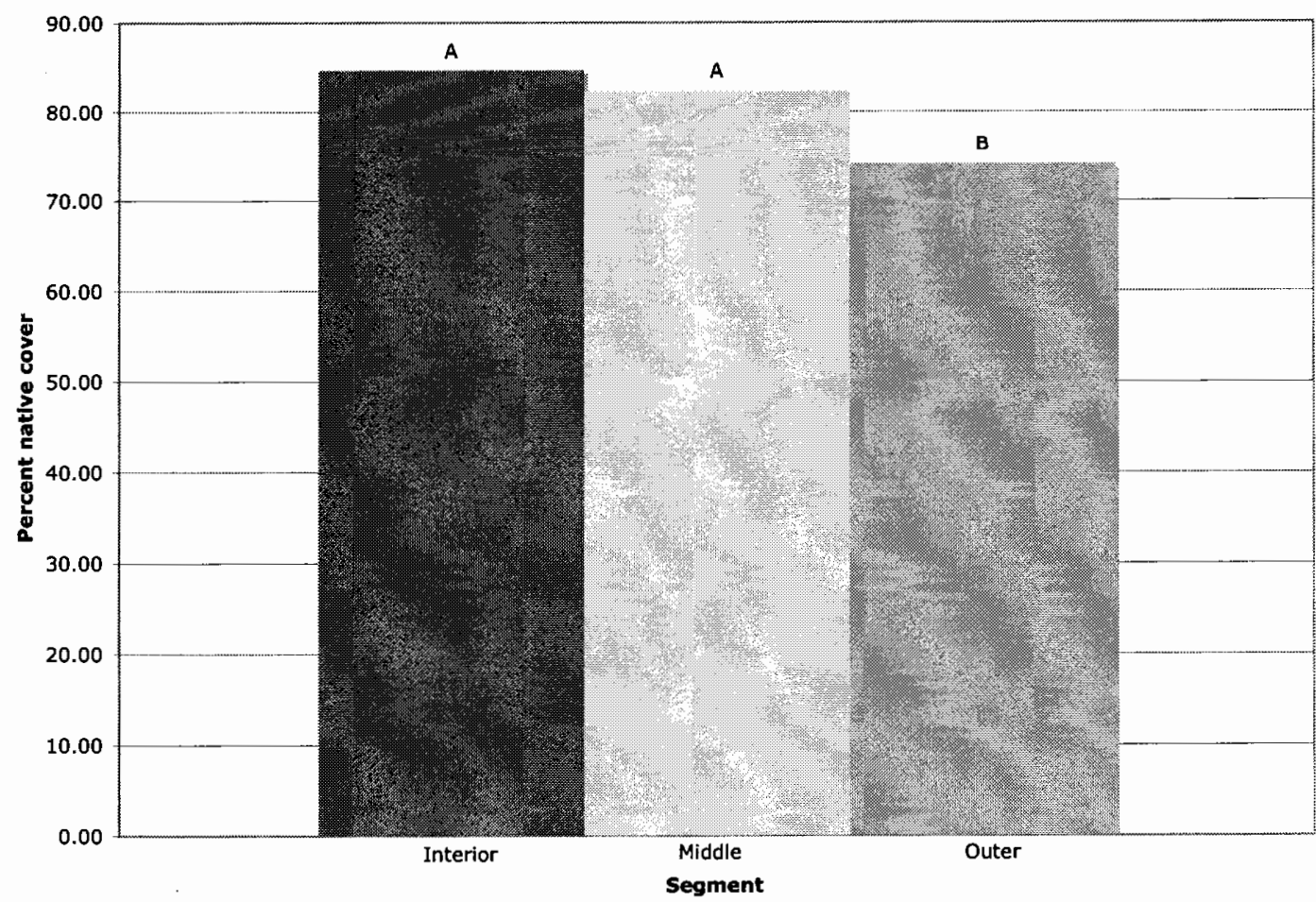

Figure 7. Percent native cover by segment for all edge types. Different letters indicate significant differences $(p<0.05)$ between edge types. Differences were determined using total native cover and transformed into percent native cover.

As edge canopy cover increased, native cover increased in road sites, but decreased in field and residential sites (Figure 8). 


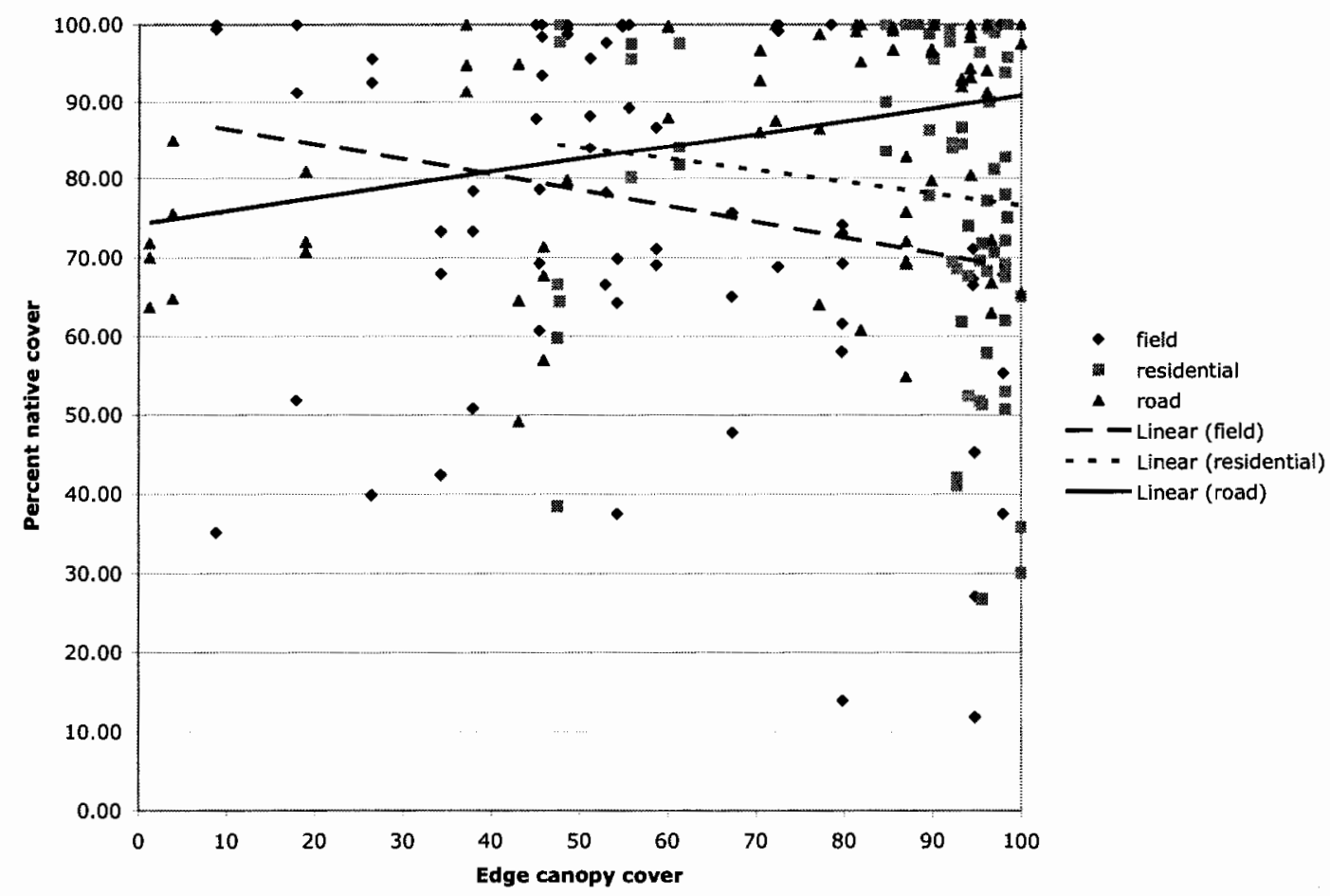

Figure 8. Relationship of native cover to edge canopy by edge type. Each symbol represents the mean native cover from one transect.

Across all sites, native cover went up with increasing interior canopy cover ( $p$ $=0.0001$ ) (Figure 9), however when individual edge types were examined, a different relationship appeared (Figure 9). Native cover on field sites increased with increasing interior canopy cover while it decreased on road and residential edges. 


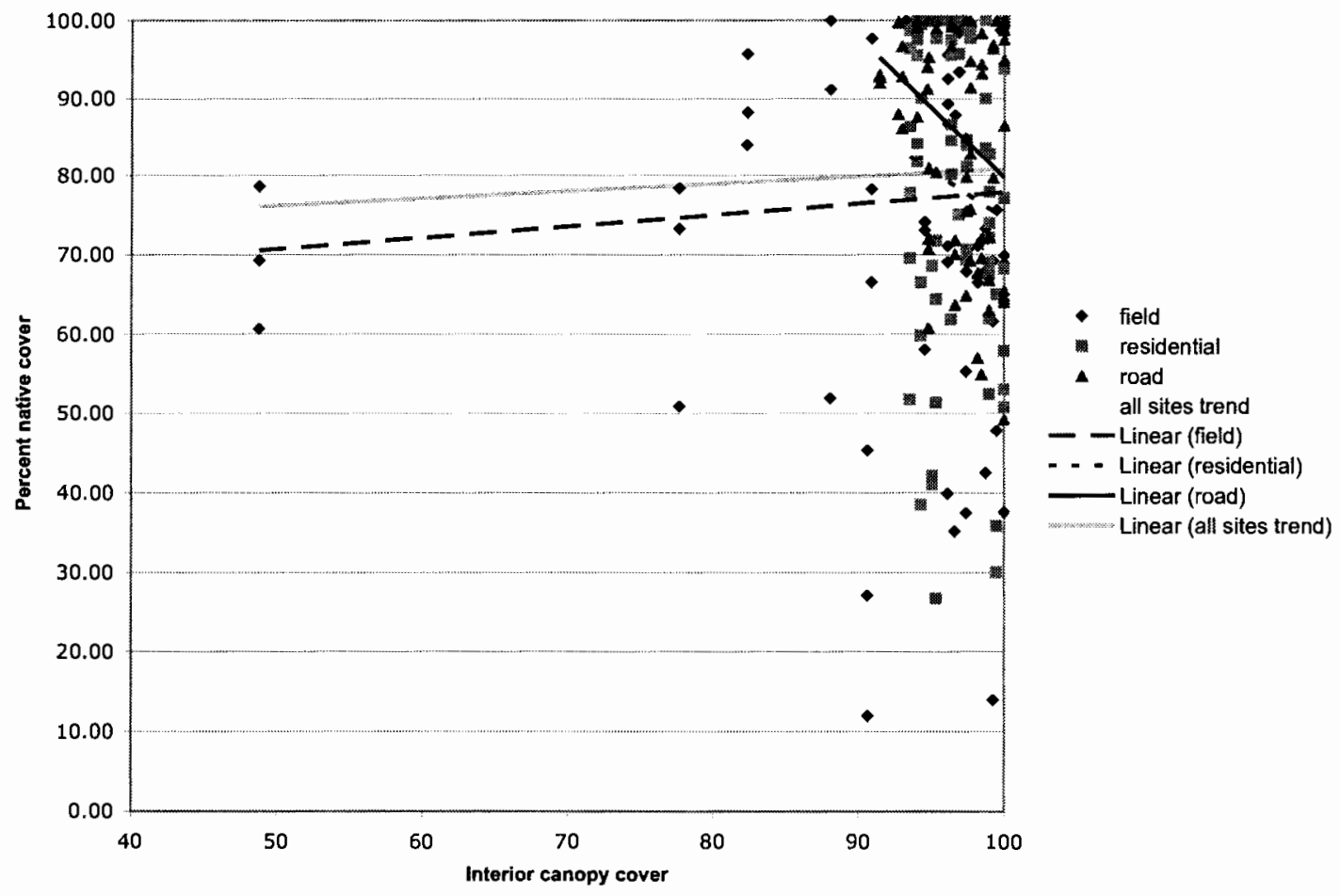

Figure 9. Percent native cover versus interior canopy by edge type. Each symbol represents the mean native cover from one transect.

Native Richness

ANOVA results showed that for all edges, native richness was not significantly different between edge types or transect segments (Table 3). ANCOVA results showed that it decreased with increasing age in field and residential sites. Road edges however, increased in native richness with increasing age $(\mathrm{p}=0.0005)$ (Figure 10). Although native cover varied by segment, native richness was statistically the same in each segment. 
Table 3. Analyses of variance or covariance for effects of abiotic factors on native richness.

\begin{tabular}{|l|l|l|l|l|l|}
\hline Source of variation & $D F$ & $\begin{array}{l}\text { Sum of } \\
\text { squares }\end{array}$ & $\begin{array}{l}\text { Mean } \\
\text { square }\end{array}$ & $\begin{array}{l}F \\
\text { value }\end{array}$ & $P>F$ \\
\hline Edge type & 2 & 18.4841 & 9.2420 & 2.3 & 0.1035 \\
\hline Segment & 2 & 0.5833 & 0.2916 & 0.07 & 0.9301 \\
\hline Age of all edges & 1 & 0.4254 & 0.4254 & 0.11 & 0.7455 \\
\hline Age $\mathrm{x}$ edge type & 2 & 62.9941 & 31.4970 & 7.82 & 0.0005 \\
\hline Edge $\mathrm{x}$ segment & 4 & 41.7222 & 10.43055 & 2.59 & 0.0381 \\
\hline Edge canopy cover & 1 & 34.9098 & 34.9098 & 8.67 & 0.0036 \\
\hline Interior canopy cover & 1 & 53.9422 & 53.9422 & 13.40 & 0.0003 \\
\hline $\begin{array}{l}\text { Edge canopy cover } \mathrm{x} \\
\text { edge type }\end{array}$ & 2 & 24.6947 & 12.3473 & 3.07 & 0.0489 \\
\hline $\begin{array}{l}\text { Interior canopy cover } \mathrm{x} \\
\text { edge type }\end{array}$ & 2 & 33.3877 & 16.6938 & 4.15 & 0.0173 \\
\hline Slope & 2 & 48.1496 & 24.0748 & 5.98 & 0.0030 \\
\hline Aspect & 1 & 1.7220 & 1.7220 & 0.43 & 0.5139 \\
\hline Edge $\mathrm{x}$ slope & 4 & 277.2776 & 69.3194 & 17.22 & $<0.0001$ \\
\hline Age $\mathrm{x}$ slope & 2 & 16.2079 & 8.1039 & 2.01 & 0.1365 \\
\hline Age $\mathrm{x}$ aspect & 1 & 9.3203 & 9.3203 & 2.32 & 0.1298 \\
\hline Slope $\mathrm{x}$ aspect & 2 & 10.8274 & 5.413 & 1.34 & 0.2631 \\
\hline
\end{tabular}




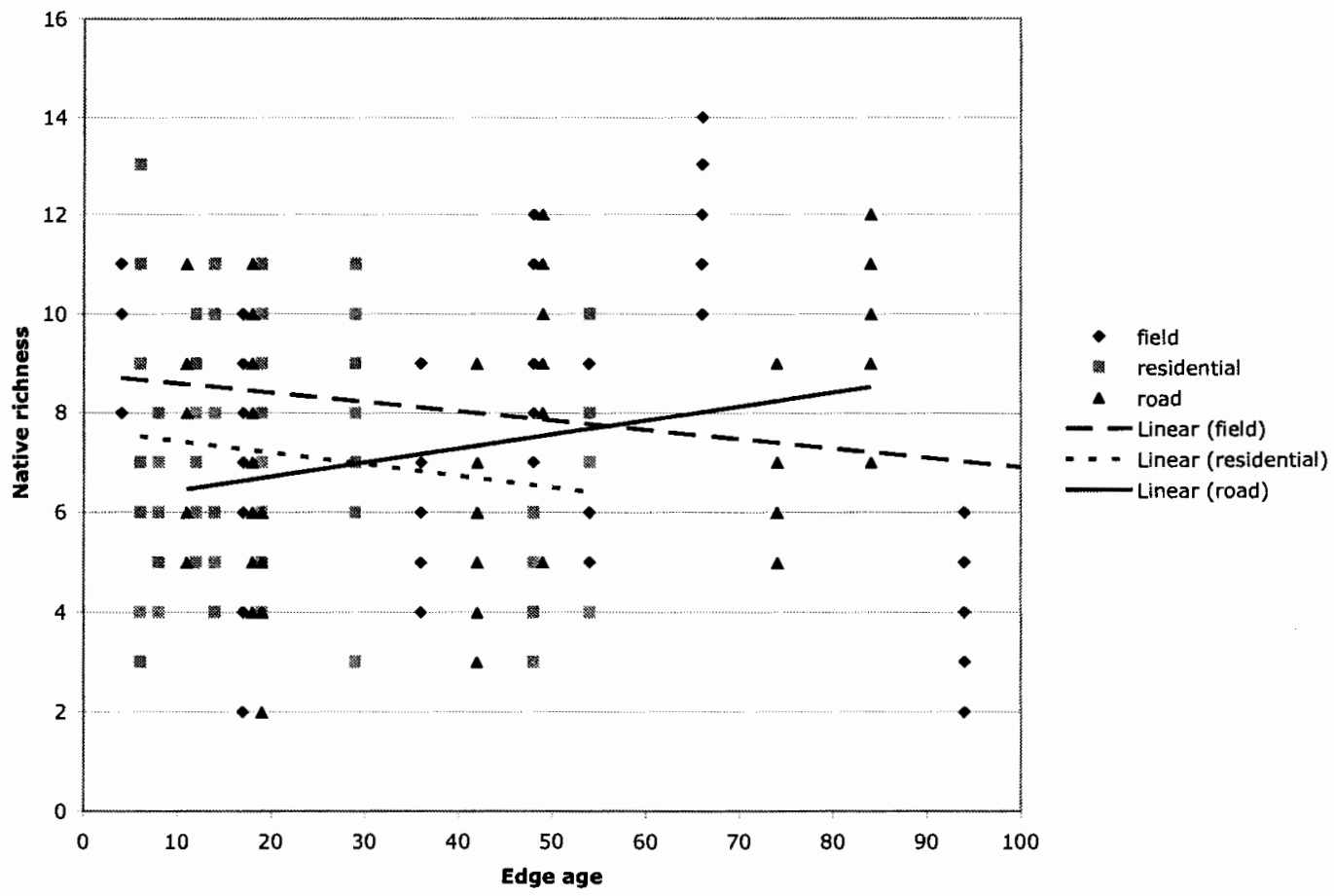

Figure 10. Mean native richness versus edge age for field, residential, and road edges. Each symbol represents the mean native richness from one transect.

Overall native richness increased across all sites as edge canopy cover increased $(p=0.0036)$. When edge types were separated out, native richness increased on road and residential edges but decreased on field edges (Figure 11). Native richness on road edges increased at a faster rate than residential edges. 


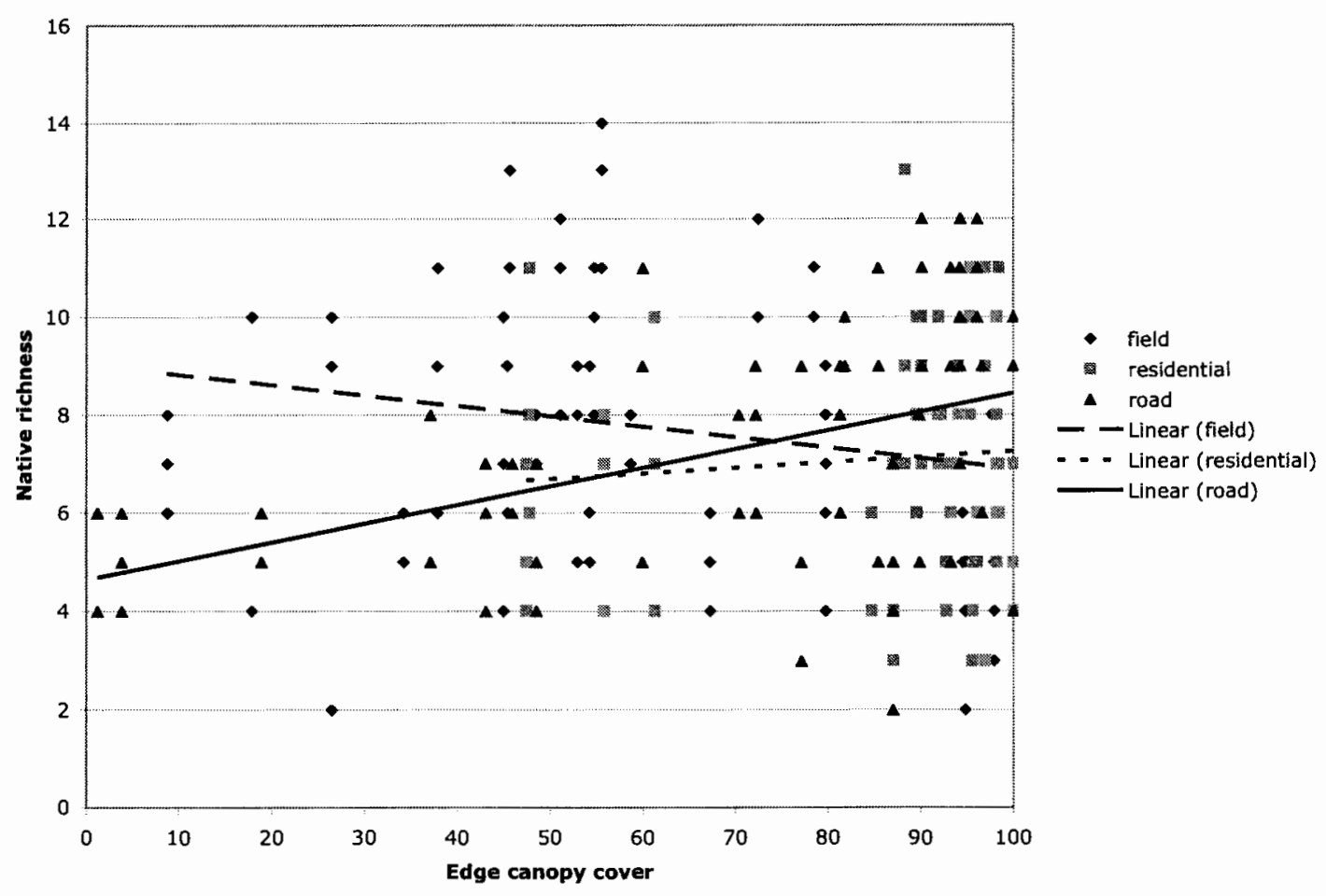

Figure 11. Mean native richness versus mean edge canopy cover for field, residential, and road edges. Each symbol represents the mean richness from one transect.

Native richness declined across all edge types as interior canopy cover increased, however it decreased more slowly in field sites than in road and residential sites (Figure 12). 


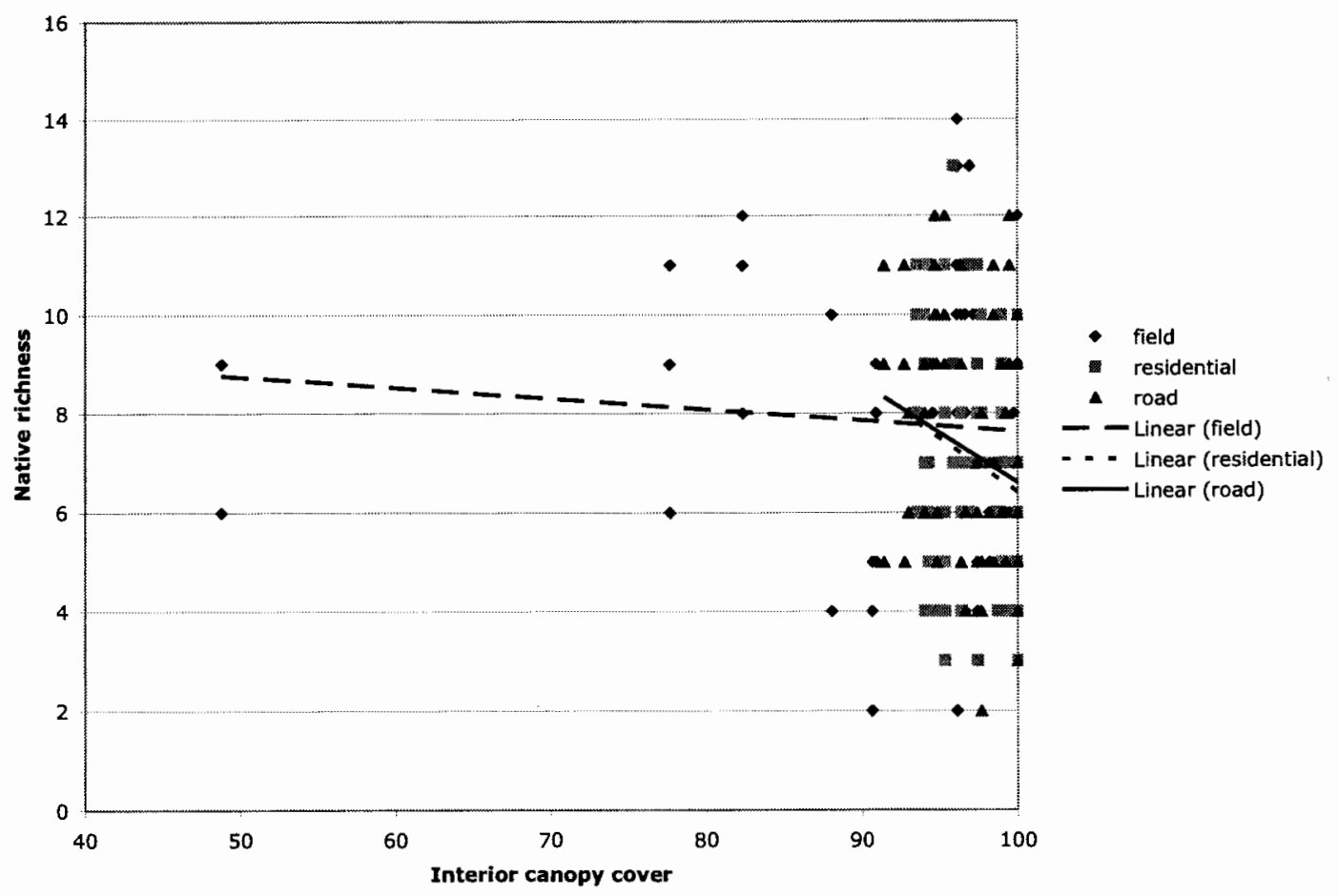

Figure 12. Mean native richness versus mean interior canopy cover for field, residential, and road edges. Each symbol represents the mean native richness from one transect.

Exotic Richness

Exotic richness varied depending on the edge type $(p=0.0056)($ Table 4$)$.

Residential sites had the highest mean exotic richness ( $p<0.0013$ ), followed by field and road edges which were statistically the same (Figure 13). 
Table 4. Analyses of variance or covariance for effects of abiotic factors on exotic richness.

\begin{tabular}{|l|l|l|l|l|l|}
\hline Source of variation & $D F$ & $\begin{array}{l}\text { Sum of } \\
\text { squares }\end{array}$ & $\begin{array}{l}\text { Mean } \\
\text { square }\end{array}$ & $F$ value & $P>F$ \\
\hline Edge type & 2 & 13.8860 & 6.9430 & 5.33 & 0.0056 \\
\hline Segment & 2 & 57.1203 & 28.5601 & 21.93 & $<0.0001$ \\
\hline Edge x segment & 4 & 14.1851 & 3.5462 & 2.72 & 0.0309 \\
\hline Edge canopy cover & 1 & 0.3852 & 0.3852 & 0.30 & 0.5871 \\
\hline Interior canopy cover & 1 & 4.2598 & 4.2598 & 3.27 & 0.0721 \\
\hline Age of all edges & 1 & 21.7566 & 21.7566 & 17.61 & $<0.0001$ \\
\hline Age x edge type & 2 & 0.2679 & 0.1339 & 0.10 & 0.9023 \\
\hline $\begin{array}{l}\text { Edge canopy cover } \mathrm{x} \\
\text { edge type }\end{array}$ & 2 & 4.5887 & 2.2943 & 1.760 & 0.1745 \\
\hline $\begin{array}{l}\text { Interior canopy cover } \mathrm{x} \\
\text { edge type }\end{array}$ & 2 & 11.5741 & 5.7870 & 4.44 & 0.0130 \\
\hline Slope & 2 & 16.0502 & 8.0251 & 6.16 & 0.0026 \\
\hline Aspect & 1 & 1.9127 & 1.9127 & 1.47 & 0.2271 \\
\hline Edge x slope & 4 & 74.4155 & 18.6038 & 14.29 & $<0.0001$ \\
\hline Age x slope & 2 & 16.5658 & 8.2829 & 6.36 & 0.0021 \\
\hline Age $x$ aspect & 1 & 1.6701 & 1.6701 & 1.28 & 0.2589 \\
\hline Slope x aspect & 2 & 18.4385 & 9.2192 & 7.08 & 0.0011 \\
\hline
\end{tabular}




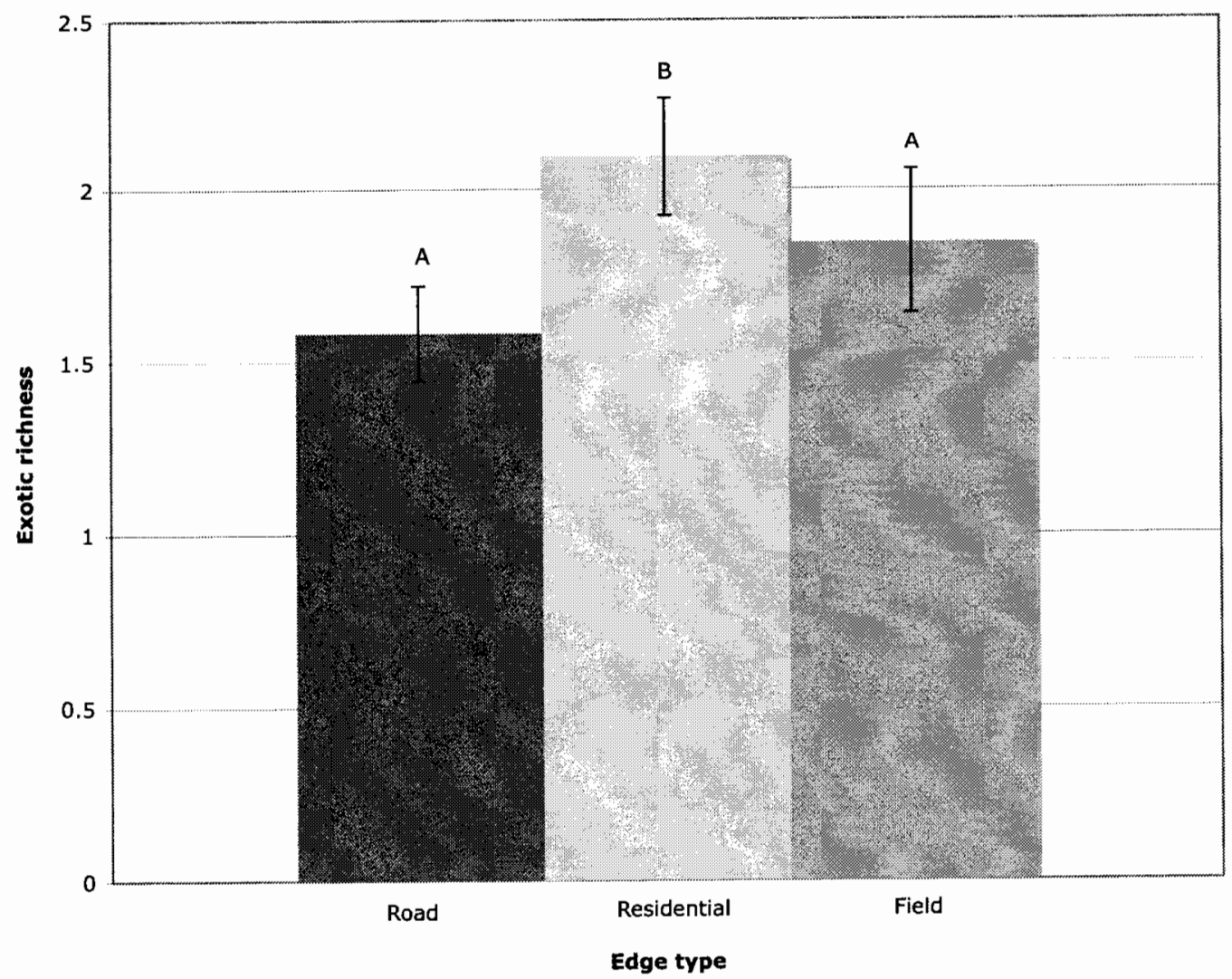

Figure 13. Mean exotic richness for road, residential, and field edges. Error bars represent 1 SE. Different letters indicate significant differences $(p<0.05)$ between edge types.

When all sites were analyzed together ANOVA tests showed that the level of exotic richness varied between segments $(p=0.0056)$ (Figure 14). Exotic richness was highest in the outer segments of all edge types $(\mathrm{p}<0.0001)$ and was statistically the same for the middle and inner segments. 


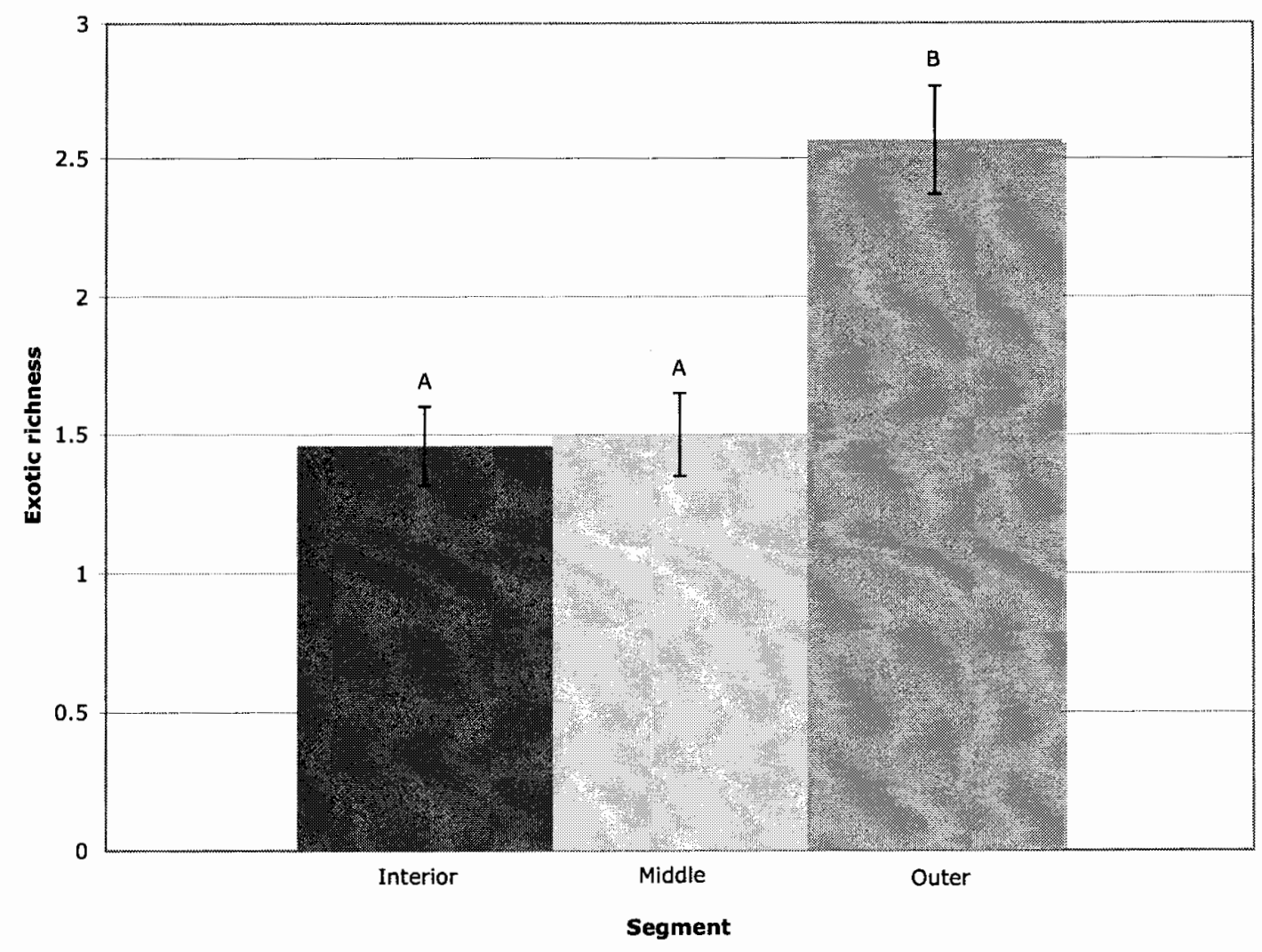

Figure 14. Exotic richness by $\mathbf{1 0} \mathbf{m}$ segment for all sites. Error bars represent 1

SE. Different letters indicate significant differences $(p<0.05)$ between edge types.

An ANCOVA test showed that the effect of age on exotic richness for all sites was highly significant $(\mathrm{p}<0.0001)$. Exotic richness increased slowly, but steadily with edge age (Figure 15). 


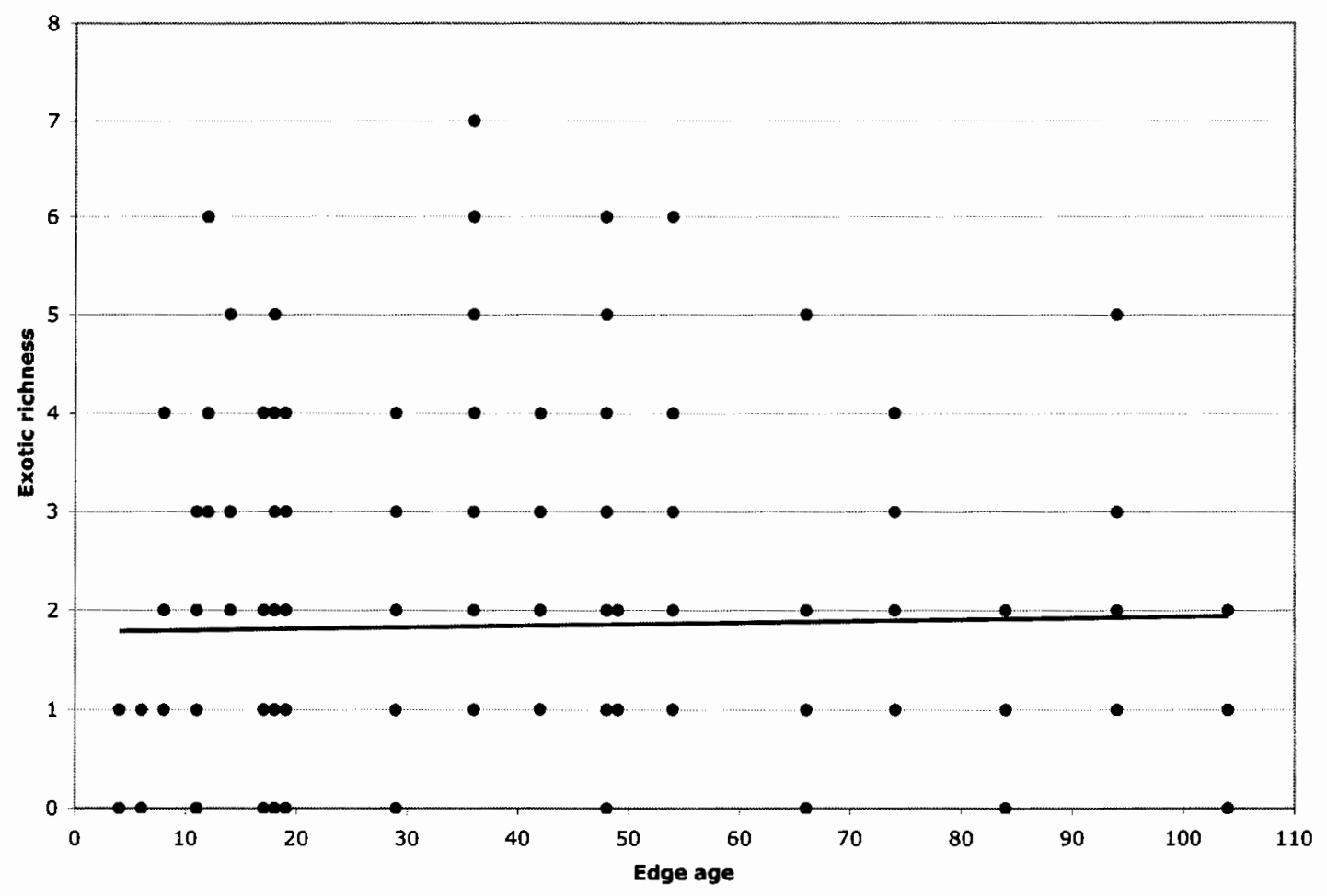

Figure 15. Relationship between exotic richness and edge age for all sites. Each dot represents a transect segment.

As interior canopy cover increased, exotic richness increased in residential and road edges, but decreased in field sites (Figure 16). No relationship with edge canopy cover was observed for individual edge types nor across all edges. 


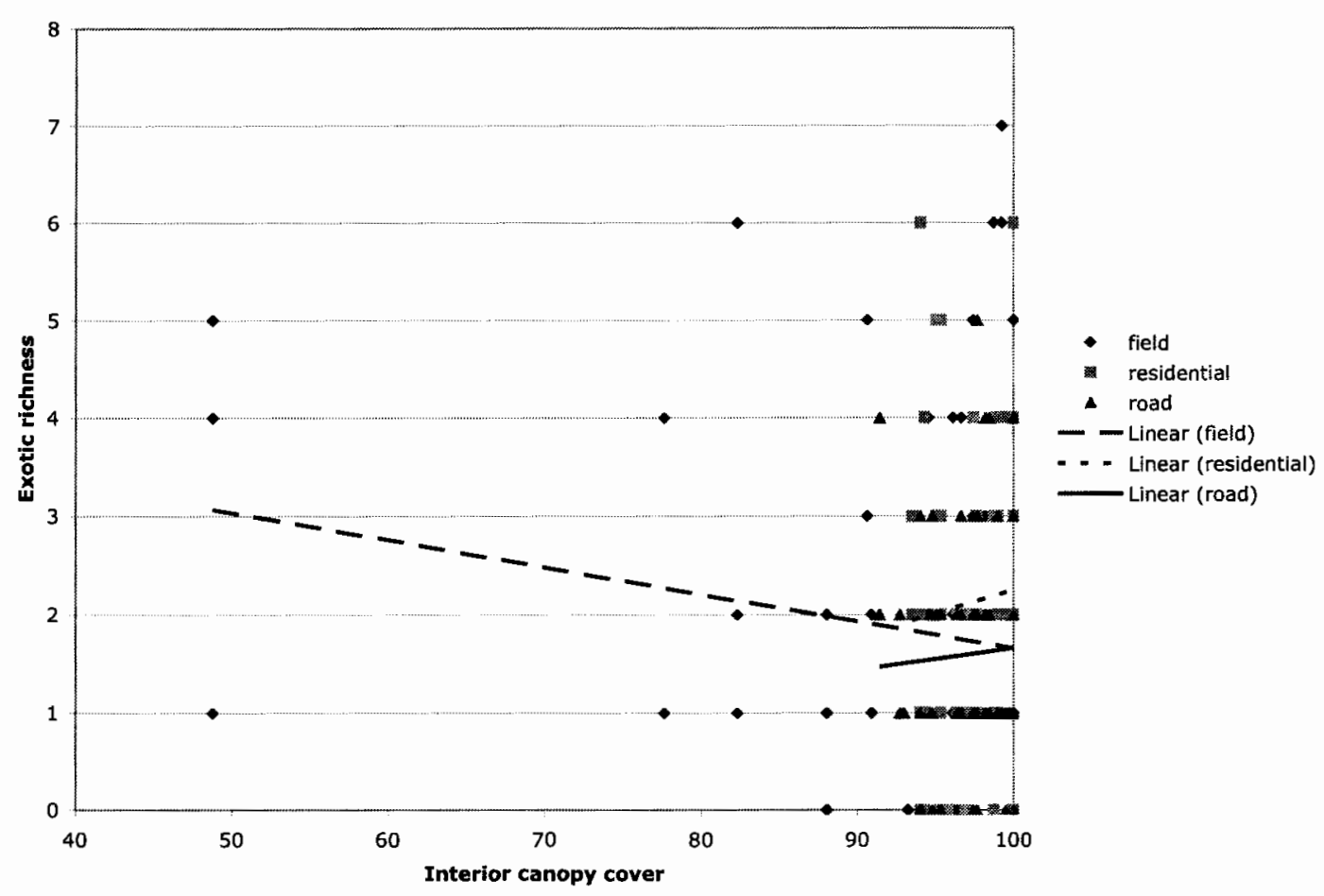

Figure 16. Exotic richness versus interior canopy cover for field, residential, and road edges. Each symbol represents the mean exotic richness from one transect.

\section{Total Species Richness}

Based on GLM analysis, mean total richness varied between edge types $(p=$ 0.0140) (Table 5) (Figure 17). Field segments showed greater total species richness than segments in residential and road sites $(p=0.0212)$ which were not statistically different from each other. 
Table 5. Analyses of variance or covariance for effects of abiotic factors on total richness.

\begin{tabular}{|l|l|l|l|l|l|}
\hline Source of variation & $D F$ & $\begin{array}{l}\text { Sum of } \\
\text { squares }\end{array}$ & $\begin{array}{l}\text { Mean } \\
\text { square }\end{array}$ & $\begin{array}{l}F \\
\text { value }\end{array}$ & $P>F$ \\
\hline Edge type & 2 & 43.4477 & 21.7238 & 4.37 & 0.0140 \\
\hline Segment & 2 & 68.4815 & 34.2407 & 6.89 & 0.0013 \\
\hline Edge $x$ segment & 4 & 16.0741 & 4.0185 & 0.81 & 0.5211 \\
\hline Edge canopy cover & 1 & 42.6299 & 42.699 & 8.58 & 0.0038 \\
\hline Interior canopy cover & 1 & 88.5193 & 88.5193 & 17.81 & $<0.0001$ \\
\hline Age of all edges & 1 & 16.0970 & 16.0970 & 3.24 & 0.0735 \\
\hline Age x edge type & 2 & 71.3090 & 35.6545 & 7.17 & 0.001 \\
\hline $\begin{array}{l}\text { Edge canopy cover x edge } \\
\text { type }\end{array}$ & 2 & 23.7500 & 11.8750 & 2.39 & 0.0945 \\
\hline $\begin{array}{l}\text { Interior canopy cover } \mathrm{x} \text { edge } \\
\text { type }\end{array}$ & 2 & 62.7746 & 31.387 & 6.32 & 0.002 \\
\hline Slope & 2 & 49.0363 & 24.5181 & 4.93 & 0.0082 \\
\hline Aspect & 1 & 7.2645 & 7.2645 & 1.46 & 0.2282 \\
\hline Edge x slope & 4 & 140.1258 & 35.0315 & 7.05 & $<0.0001$ \\
\hline Age $x$ slope & 2 & 50.3034 & 25.1517 & 5.06 & 0.0072 \\
\hline Age x aspect & 1 & 18.8813 & 18.88130 & 3.80 & 0.0528 \\
\hline Slope $x$ aspect & 2 & 17.6066 & 8.8033 & 1.77 & 0.1729 \\
\hline
\end{tabular}




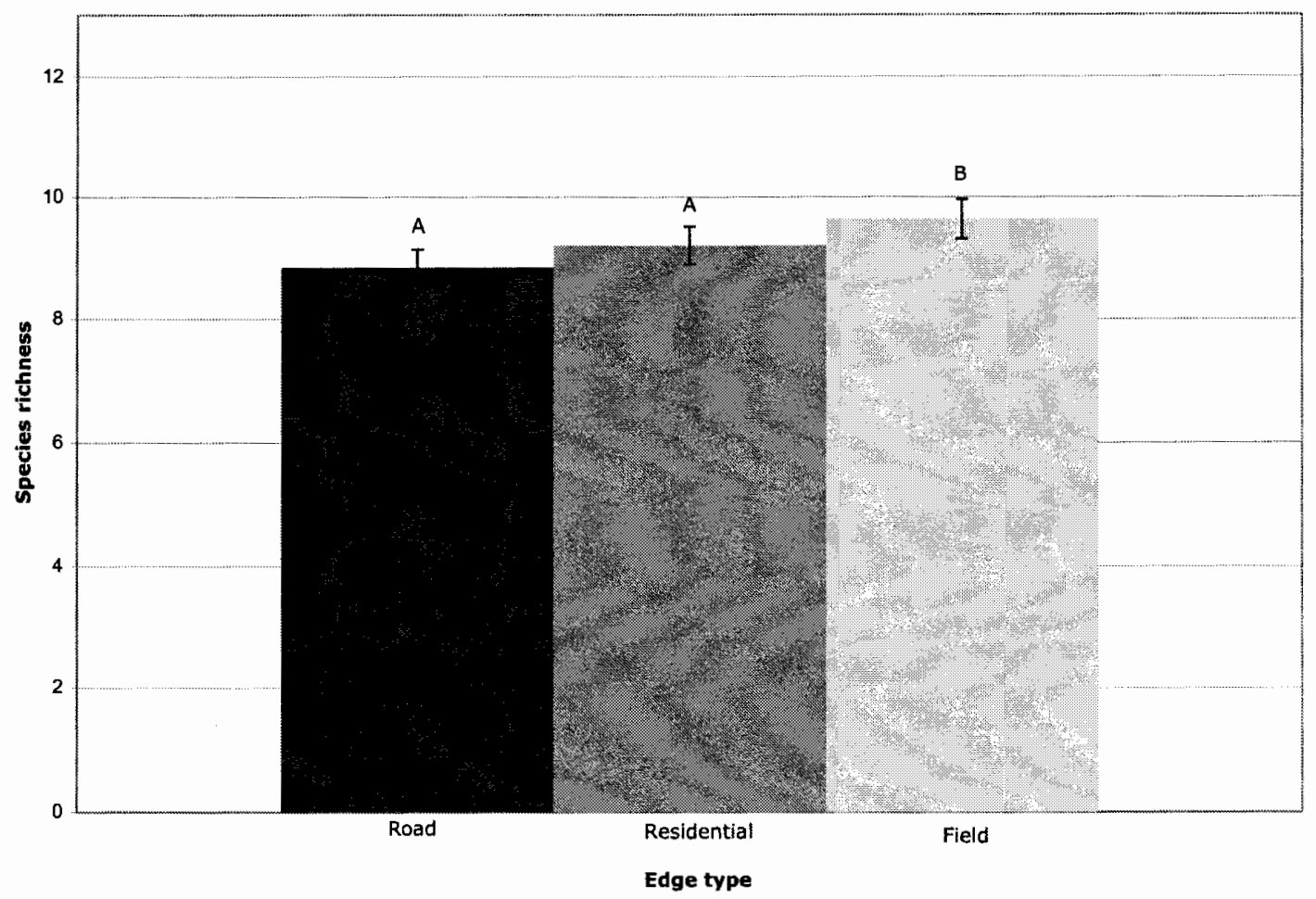

Figure 17. Mean species richness by edge type. Error bars represent 1 SE.

Different letters indicate significant differences $(p<0.05)$ between edge types.

ANCOVA results indicated that the location of different segments within each transect had a significant effect on total richness $(p=0.0013)$ for all edge types. Total richness was highest in the outer segment of all edge types $(p=0.0015)$ and was statistically the same for the middle and interior segments (Figure 18). 


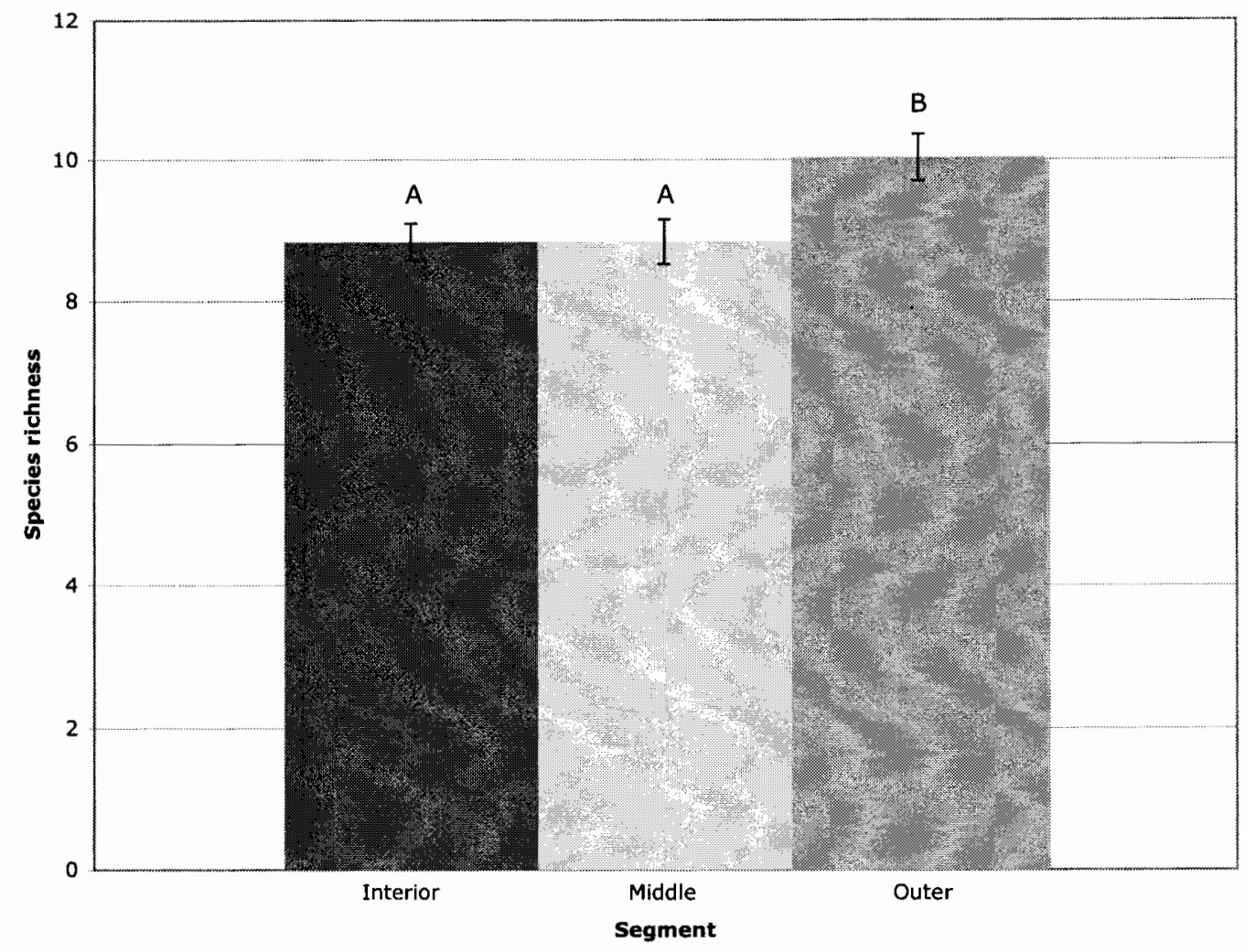

Figure 18. Mean species richness per segment for all sites. Error bars represent 1 SE. Different letters indicate significant differences $(p<0.05)$ between segments.

An ANCOVA test showed that total richness in field and residential sites decreased as edge ages increased, however it increased in road sites $(p=0.0010)$ (Figure 19). 


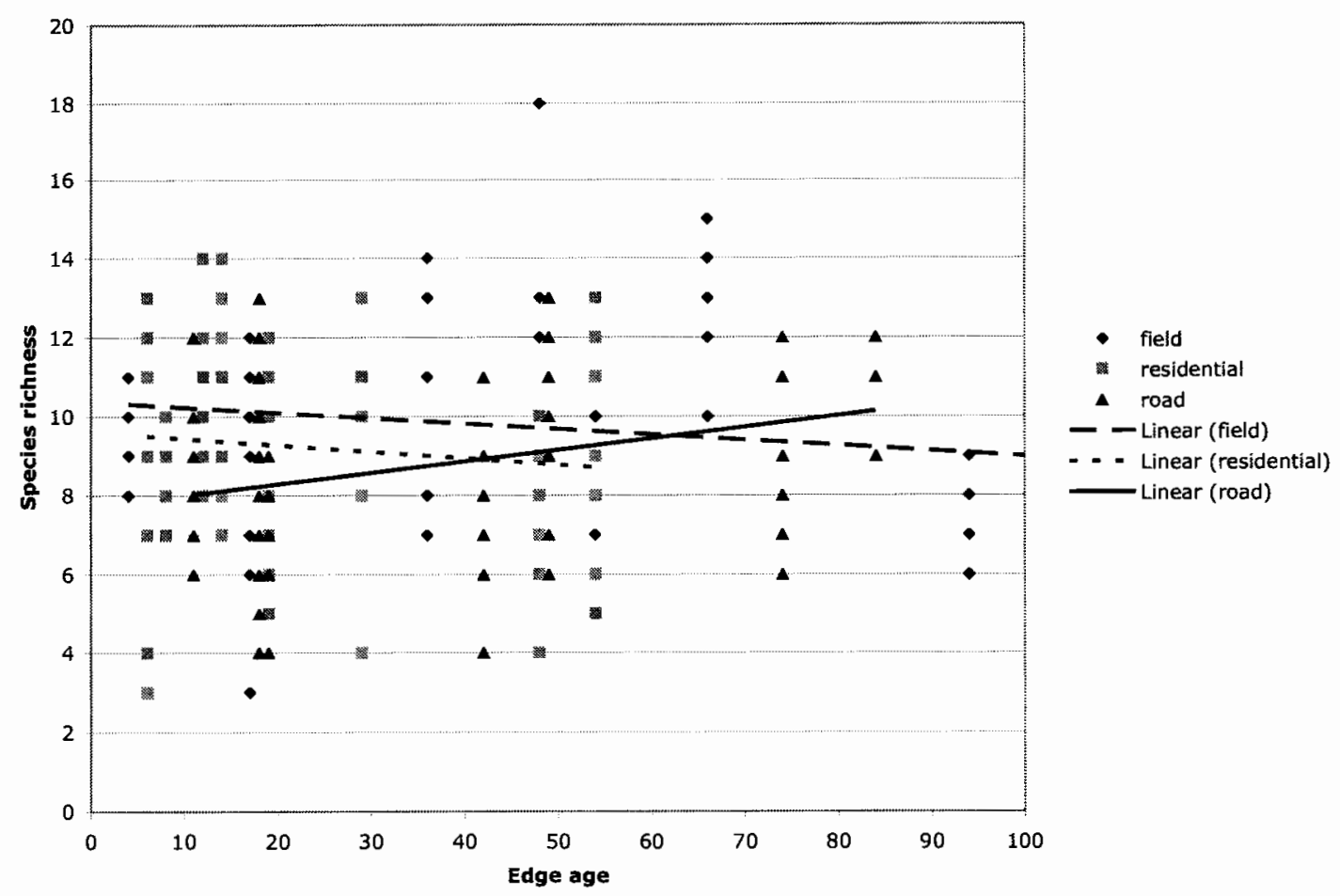

Figure 19. Mean species richness versus edge age for field, residential, and road edges. Each symbol represents the mean species richness from one transect.

As edge canopy cover increased across all sites, total richness also increased ( $\mathrm{p}$ $=0.0038)$ (Figure 20), but showed a decrease with increasing interior canopy cover $(\mathrm{p}$ $<0.001$ ) (Figure 21). 


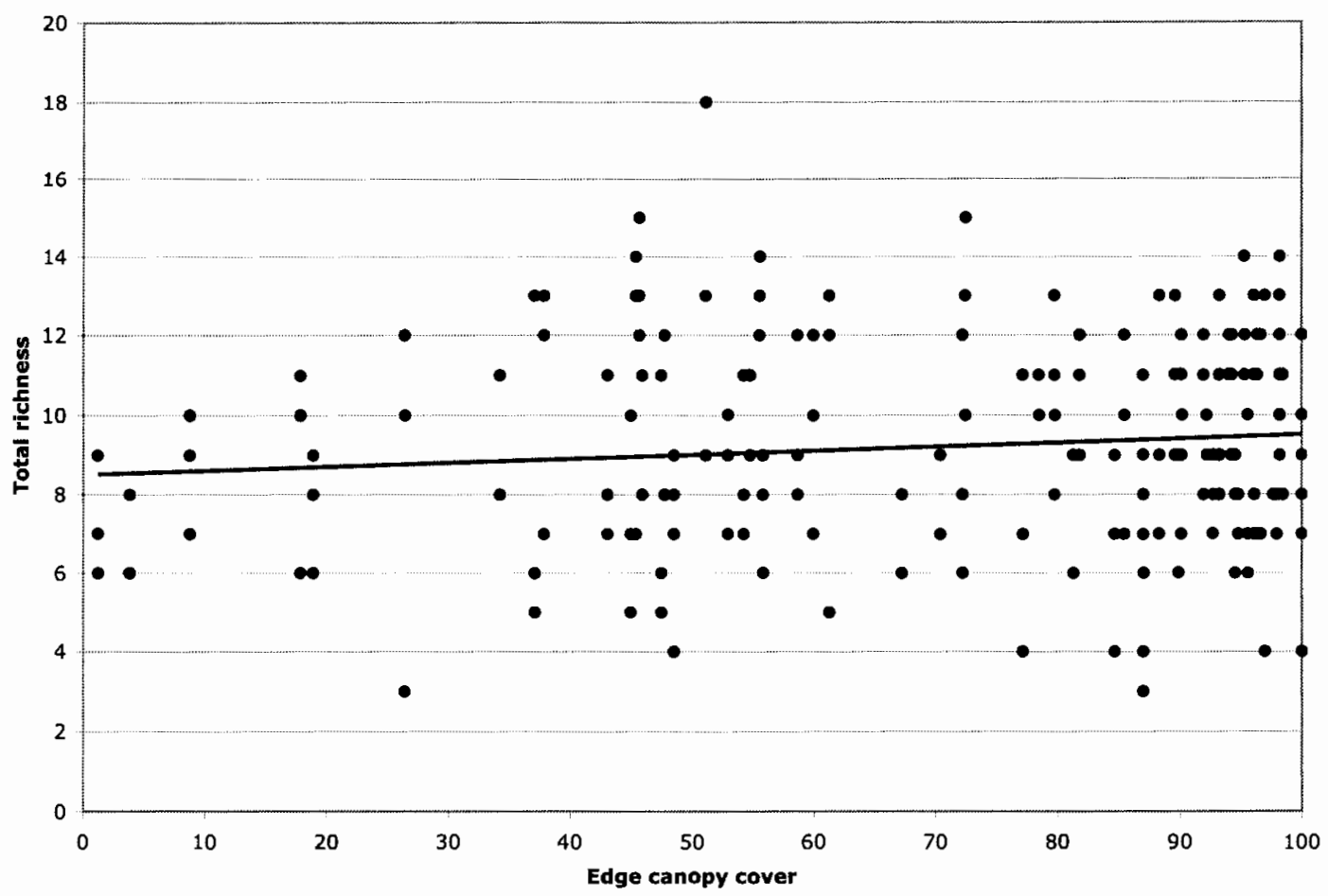

Figure 20. Relationship between total species richness and edge canopy cover for all sites. Each dot represents a transect segment. 


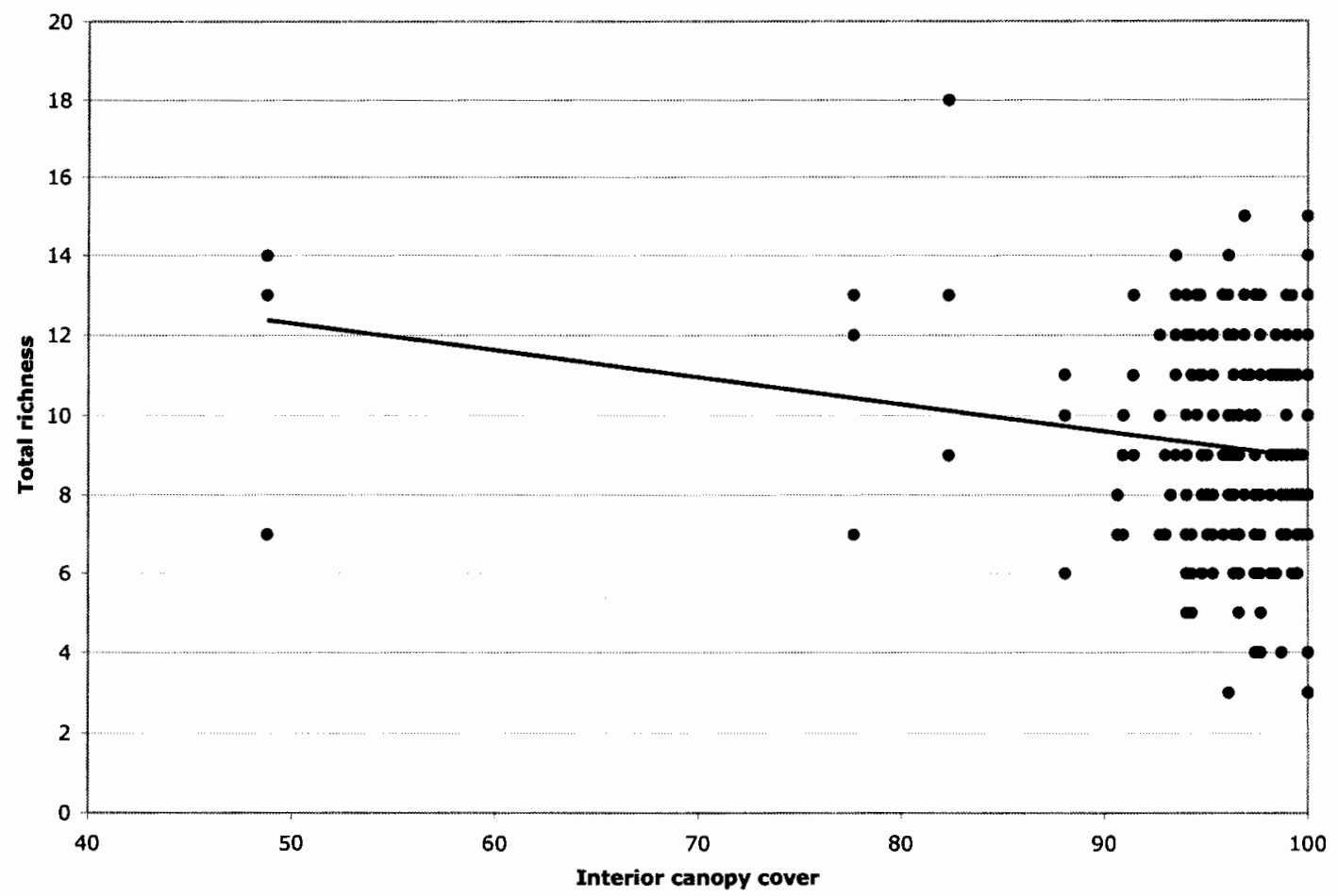

Figure 21. Relationship between total species richness and interior canopy cover for all sites. Each dot represents a transect segment. 


\section{Discussion}

\section{Native Cover and Richness}

This study found that road edges had significantly higher native cover than field or residential edges. This led to the rejection of the null hypothesis which stated that all adjacent land uses would have the same effect on species composition. These results contradict the prediction by Gelbard and Belnap (2003) that paved roads should have extremely high levels of exotic plants. On the other hand it does not refute research that has implicated roads as major sources of weed seeds as supported by Parendes and Jones (2000), since the road edges were impacted by exotic plants. Roads had approximately $86 \%$ native cover. However, what this study highlights is that other types of edges may have greater negative impacts on native forest communities. Field and residential edges each had native cover values of approximately $78 \%$. Residential edges suffered from low native cover, high exotic species richness, and moderate levels of native richness.

While the preservation of native richness is important in the long term, cover or dominance of native plants is equally or perhaps more important. If native plants are not dominant in the landscape, their chances of exchanging genetic information within fragments and maintaining viable population sizes in the long term could be threatened (Hutchinson and Vankat 1997).

The null hypothesis that the age of the edge would not affect the species composition of the edge was rejected. With increasing age, native species richness increases in road edges. However, native richness decreases on field and residential 
edges over time. I put forward the explanation that since roads have abrupt, well defined edges that do not change over time, unlike field or residential edges, and since it is likely that fewer people are entering forests from road edges than from fields or residences, the amount of physical disturbance there is lower. This lower level of disturbance could foster the development of greater native cover since native plants in these areas have less competition from exotic species.

There are a number of potential reasons for the decline along field and residential edges. One explanation for the decline could be due to what Pysek et al. (2002) and Quinn and Harrison (1988) termed "relaxation", which is a fragment's inability to sustain a full suite of species without access to the resources of adjacent forests. The pattern could also be a result of varying disturbance regimes which are in place on the different edges. Studies have reported that exotic plants recruit in areas with high disturbance levels (Knops et al. 1995), therefore a similar pattern could be in place in field and residential edges. My study showed that an increase in exotic plants can displace natives over time, which could also explain the decline in field and residential edges.

The time frame of this study does not adequately capture the potential long term outcome of plant community changes. The forests examined in this study are all second growth and less than 150 years old. Schoonmaker and McKee (1988) found that second growth Douglas fir forests reached peak richness at 20 years and showed the lowest richness values at 40 years, as canopy closure occurred. Douglas-fir can live for up to 750 years, while other species which may become dominant in a forest, 
such as western hemlock, may not be abundant until fir trees are 50 to 100 years old (Franklin and Dyrness 1973). Therefore the results we are seeing at this point in time may not be indicative of the plant community which could develop in the future.

If the amount of native plant cover can be viewed as a measure of habitat health (Magee et al 1999), road edges appear to be healthier than field or residential edges. Although Magee studied the effect of urban land use on plant species presence in wetlands, I wondered whether similar patterns of invasions of exotic plants could be found in my results. Comparing my results to this study, no transferable pattern could be discerned. In their study transportation/industrial areas had high levels of exotics compared to other land uses, but this land uses showed relatively low exotic values in my study. Other research has looked at edge effects in forests, but few have examined the effects of urban land uses (Bastin and Thomas 1999, Honnay, et al 1999b). Bastin and Thomas found that the occurrence of target plant species increased when similar habitats were nearby. While my study did not directly look for similar habitats, the occurrence of exotic plants in forests increased along residential edges where said plants are often cultivated. This makes sense, since humans who reside along shady forest edges would likely garden with shade-tolerant plants which would easily survive in forest conditions.

\section{Exotic Richness and Cover}

Exotic cover was lowest on road edges and statistically the same on field and residential sites. Exotic richness was found to be highest in residential edges, while 
field and road edges had lower levels of exotics. In residential edges, not only is the amount of disturbance likely higher from activities such as yard debris dumping, children playing, or people exploring, but there are a plethora of potential weed species (including ornamental plants) that could escape into the forests.

It stands to reason that invasive exotic plants would recruit and invade from the edges. Studies by Forman (1995) and Cadenasso and Picket (2001) both describe the potential effects of the vegetative structure of the edge. They point to the ability of vegetation to block light and wind dispersed seeds: the results imply that structure may not be the biggest problem. This research project found that the amount of canopy cover on the edge of the forest did not influence the amount of exotic cover there. More telling, the dominant exotic species (English ivy, Himalayan blackberry, and sweet cherry) in these urban fragments are not wind dispersed as seen in Meekins and McCarthy (2001). English ivy can be spread vegetatively through a segment of a vine, rooting along a stem, or via seed in bird droppings (Clergeau 1992). Himalayan blackberry is dispersed via birds and mammals (Hoshovsky 2000). With its heavy pits, sweet cherry is animal dispersed as well (Edlin 1985). A majority of other exotic plants found were herbaceous. Although herbaceous plants did not represent a large portion of exotic cover, species which emerge in early spring such as garlic mustard (Alliaria petiolata) can dominate moisture and other resources on a small scale, leading to a decrease in native herbaceous plants such as spring wildflowers (Nuzzo 2000). 
Increasing interior canopy cover on both road and residential edges led to a rise in exotic cover and richness. This shows that shade-tolerant weeds are recruiting on these sites. If said weeds are able to recruit without a disturbance or change in canopy cover, they could prove a long term threat to native species. On field edges, however, an increase in interior canopy cover led to an increase in native cover and a decrease in exotic richness. This implies that different weed species may be present. It stands to reason that weeds on this edge type are better adapted to high light conditions and as they get deeper into the shady forest interior they decline in number and area. Further analysis of the data set is needed to confirm these observations. Native richness also shows a negative relationship with interior canopy cover. This is an expected result, since fewer species are able to survive in the low light conditions found in forest interiors. These results are similar to those found in riparian areas by Sharp (2002).

It is interesting to note that while exotic species richness was related to light levels (canopy cover) on the interior, there was no relationship with light on the outside edge of the forest. Exotic and total richness however was highest the outermost $10 \mathrm{~m}$ segment in all transects. Since this observation appears to have little influence due to light, it implies that the outer $10 \mathrm{~m}$ are a highly competitive area due to the concentration of seeds which accumulate and germinate there (Luken, et al. 1991).

Another threat to native richness is the fact that exotic richness increases with age in all edge types. Combining this trend with the decrease in native richness in 
field and residential sites could lead to greater declines in native forest communities.

Changes in communities with emigrating species over time is illustrated in the Theory of Island Biogeography (MacArthur and Wilson 1967). In the urban environment it appears that most of the emigrants are exotics. Although road edges showed the opposite trend; native richness continued to increase with age even though exotic richness was also increasing. Why this trend is so different on road edges than other types of edges is unclear from the data collected in this study.

\section{Management Implications}

The large component of the exotic tree, sweet cherry, is unexpected. It is not widely mentioned in the literature as an invasive plant nor is it widely discussed as a problem by regional land managers. Sweet cherry can reproduce from seed or sucker without a disturbance and grows in both bright and shady conditions (Evans 1988). The possibility that a canopy height tree could compete with or out-compete native trees and shrubs could be detrimental to forest health in the long term.

Following the advice of Saunders (1991) that land managers must learn to deal with external influences on reserves, there are some important lessons from this study they should consider. While roads showed some advantages over other edges, they should not necessarily be viewed as a panacea for conservation. Land managers should consider Connell's (1978) intermediate disturbance hypothesis which states that the highest levels of diversity are found in areas with intermediate levels of disturbance. This disturbance allows a variety of different species to occur, but may also promote 
exotic species. Roadsides maintenance often involves mowing or herbicide application to prevent vegetation from encroaching onto the road. This vegetation maintenance provides relatively low or intermediate levels of disturbance, but in a consistent location and with regular timing. It may be possible that this level of disturbance keeps competition at a middle level by "resetting" the edge, which leads to an early successionary stage. This in turn could lower the number or amount of exotic species entering the forest and competing with native vegetation, since many plants may not have a chance to either set seed or vegetatively creep into the forest. Similar treatments on residential and field edges could prove beneficial.

In addition to regular plant species inventories, managers should pay particular attention to the first ten meters of all forest edges since those areas consistently showed the lowest native cover and the highest exotic diversity. Although individual sites may vary, from a planning perspective, land managers may wish to allocate greater resources towards the protection of residential or field forest edges. 


\section{Conclusions}

This study found that road edges had significantly higher native cover than field or residential edges. Research has implicated roads as major sources of weed seeds (Parendes 2000, Gelbard 2003), a finding this study does not refute. However, other types of urban land uses may have greater impacts on native forest communities; residential areas are a particular concern because they showed low native cover, moderate levels of native richness, and high levels of exotic richness. Residential edges were also the most common land use encountered along forest edges (personal observation).

As road edges age, native species richness increases. However, native richness decreases on field and residential edges over time. This implies that varying disturbance regimes are in place on the different edges. Roads have an abrupt, hard edge that does not change over time, unlike field or residential edges, and since it is likely that fewer people are entering forests from road edges than from fields or residences, perhaps the amount of disturbance there is lower. Either the regular maintenance practices along road edges or this lower level of disturbance could foster the development of greater native species richness and cover.

Increasing interior canopy cover in residential and road edges led to a rise in exotic cover and richness. This shows that shade-tolerant weeds may be a threat to native forest species preservation. On field edges, however, an increase in interior canopy cover leads to an increase in native cover and a decrease in exotic richness, which may be a result of sun loving field species failing to establish in the shade. 
Since there are few published studies of urban forest fragments in the Pacific Northwest, the results of this study provide new perspectives for urban forest management. Managers should reconsider their opinions about roads and re-examine which exotic species are present on their lands. Future research should examine measures of disturbance in road, field, and residential edges to determine ways to increase native plant richness and cover. Research should also examine measures of direct impacts (such as human trampling, vegetation cutting, or soil disturbance) in road, field, and residential edges to determine ways to increase native plant richness and cover. Without a better understanding of these impacts and a possible means to reduce them, native richness will decline in urban areas. 


\section{Literature Cited}

Bastin, L. and C.D. Thomas. 1999. The Distribution of Plant Species in Urban Vegetation Fragments. Landscape Ecology. 14:493-507.

Begon, M, J.L. Harper, and C.R. Townsend. Ecology: individuals, populations, and communities. Cambridge, MA: Blackwell Scientific Publications; 1990.

Bhuju, D.R., and M. Ohsawa. 1997. Effects of nature trails on ground vegetation and understory colonization of a patchy remnant forest in an urban domain. Biological Conservation. 85:123-135.

Blake, J.G. and J.R. Karr. 1987. Breeding Birds of Isolated Woodlots: area and habitat relationships. Ecology. 68:1724-1734.

Bolger, D.T., A.C. Alberts, R.M. Sauvajot, P. Potenza, C. McCalvin, D. Tran, S. Mazzoni, and M.E. Soule. 1997. Response of rodents to habitat fragmentation in coastal southern California. Ecological Applications. 7(2): 552-563.

Bonham, C.D. Measurements for Terrestrial Vegetation. New York: John Wiley \& Sons; 1989.

Brand, L.A. and T.L. George. 2001. Response of Passerine Birds to Forest Edge in Coast Redwood Forest Fragments. The Auk. 118:678-686.

Brothers, T.S. and A. Spingarn. 1992. Forest Fragmentation and Alien Plant Invasion of Central Indiana Old-Growth Forests. Conservation Biology. 6(1): 91-100.

Brookes, M.H. editor. Disturbance and Forest Health in Oregon and Washington. General Technical Report PNW-GTR-381. Portland, OR: USDA Forest Service, Portland; 1996.

Brower, J.E., J.H. Zar, and C.N. von Ende. Field and Laboratory Methods for General Ecology. New York: McGraw-Hill Companies Inc.; 1998.

Burke, D.M., and E. Nol. 1998. Edge and Fragment Size Effects on the Vegetation of Deciduous Forests in Ontario, Canada. Natural Areas Journal. 18:45-53

Cadenasso, M.L., and S.T.A. Pickett. 2001. Forest-Edge Permeability and Seed Flux. Conservation Biology. 15:91-97.

Clergeau, P. 1992. The effect of birds on seed germination of fleshy-fruited plants in temperate farmland. Acta Oecologica. 15(6):679-686. 
Connell, J.H. 1978. Diversity in Tropical Rainforests and Coral Reefs. Science. 199:1302-1310.

Curtis, J.T. 1956, in Burgess, R.L and Sharpe, D.M. Forest Island Dynamics in ManDominated Landscapes. New York: Sorubger-Verkag Inc.; 1981.

Deutschewitz, K., A. Lausch, I. Kuhns, and S. Klotz. 2003. Native and alien plant species richness in relation to spatial heterogeneity on a regional scale in Germany. Global Ecology \& Biogeography. 12: 299-311.

Dill, H.W., and Otte, R.C. 1971, in Burgess, R.L and Sharpe, D.M. Forest Island Dynamics in Man-Dominated Landscapes. New York: Sorubger-Verkag Inc.; 1981.

Diamond, J.M., and E. Mayr. 1976. The species-area relation for birds of the Solomon Archipelago. Proceedings of the National Academy of Science of the USA. 73: 262266.

DLCD. 1992. What is an urban growth boundary? Oregon Department of Land Conservation and Development, Salem, OR.

Dytham, C. Choosing and Using Statistics: a biologist's guide. Malden, MA: Blackwell Publishing: 2003.

Edlin, H.L. Broadleaves. Forest Commission Booklet 20. London, UK: HM Stationary Office: 1985.

Elzinga, C.L., D.W. Salzer, J.W. Willoughby, and J.P. Gibbs. Monitoring Plant and Animal Populations. Cambridge, MA: Blackwell Scientific Publications; 2001.

Englund, S.R., J.J. O'Brien, and D.B.Clark. 2000. Evaluation of digital and film hemispherical photography and spherical densiometry for measuring forest light environments. Canadian Journal of Forest Research. 30: 1999-2005.

Evans, J. Natural Regeneration of Broadleaves. Forestry Commission Bulletin 78. London, UK: HM Stationary Office. 1988.

Forman, R.T.T. Land Mosaics: The Ecology of Landscapes and Regions. Cambridge, UK: Cambridge University Press; 1995.

Franklin, J.E., and C.T. Dyrness. Natural Vegetation of Oregon and Washington. Portland, Or. : Pacific Northwest Forest and Range Experiment Station, Forest Service, U.S. Dept. of Agriculture [for sale by the Supt. of Docs., U.S. Govt. Print. Off., Washington], 1973. 
Gelbard J.L., and J. Belnap. 2003. Roads as Conduits for Exotic Plant Invasions in a Semiarid Landscape. Conservation Biology. 17(2): 420-432.

Gerig, A.J. Soil survey of Clackamas County area, Oregon. Washington, D.C.: United States Department of Agriculture, Soil Conservation Service; 1985.

Godefroid, S., and N. Koedam. 2003. Distribution pattern of the flora in a peri-urban forest: an effect of the city-forest ecotone. Landscape and Urban Planning. 65: 169185.

Green, G.L. Soil survey of Multnomah County, Oregon. Washington, D.C.: United States Department of Agriculture, Soil Conservation Service; 1983.

Green, G.L. Soil survey of Washington County, Oregon. Washington, D.C.: United States Department of Agriculture, Soil Conservation Service; 1982.

Gregg, J.W., C.G. Jones, and T.E. Dawson. 2003. Urbanization effects on tree growth in the vicinity of New York City. Nature. 434(6945): 183-187.

Gutzwiller, K.J. editor. Applying Landscape Ecology in Biological Conservation. New York: Sorubger-Verkag Inc.; 2002

Hagar, J.C. 1999. Influence of Riparian Buffer Width on Bird Assemblages in Western Oregon. Journal of Wildlife Management. 63:484-496.

Hennings, L.A., and W.D. Edge. 2003. Riparian Bird Community Structure in Portland, Oregon: Habitat, Urbanization, and Spatial Scale Patterns. The Condor. 105: 288-300.

Heywood, V.H. Patterns, extents and modes of invasions by terrestrial plants. Pages 31-60 in J.A. Drake, H.A. Mooney, F. di Castri, R.H. Groves, F.J. Kruger, and M. Williamson, eds. Biological Invasions: a Global Perspective. Chichester, UK: John Wiley: 1989.

Hitchcock, C.L. and A. Cronquist. Flora of the Pacific Northwest. Seattle, WA: University of Washington Press; 1973.

Hobbs, R.J. and L.F. Huenneke. 1992. Disturbance, Diversity, and Invasion: Implications for Conservation. Conservation Biology. 6:324-337.

Hogan, E.L. Sunset Western Garden Book. Menlo Park, CA: Lane Publishing Co.: 1988. 
Honnay, 0., P. Endels, H. Vereecken, and M. Hermy. 1999a. The Role of Patch Area and Habitat Diversity in Explaining Native Plant Species Richness in Disturbed Suburban Forest Patches in Northern Belgium. Diversity and Distributions. 5:129-141

Honnay, O., M. Hermy, and P. Coppin. 1999b. Effects of Area, Age and Diversity of Forest Patches in Belgium on Plant Species Richness, and Implications for Conservation and Reforestation. Biological Conservation. 87:73-84.

Hoshovsky, M.C. Rubus discolor. In: Bossard C.C., J.M. Randall, M.C. Hoshovsky (eds). Invasive plants of California's wildlands. pp. 277-281. Berkeley, CA:

University of California Press; 2000.

Hutchinson, T.F., and J.L. Vankat. 1997. Invasibility and Effects of Amur Honeysuckle in Southwestern Ohio Forests. Conservation Biology. 11:1117-1124.

Jules, E.S., M.J. Kauffman, W.D. Ritts, and A.L. Carroll. Spread of an invasive pathogen over a variable landscape. A non-native root rot on Port Orford cedar. Ecology. 83(11): 3167-3181.

Knops, J.M., J.R. Griffin, and A.C. Royalty. 1995. Introduced and Native Plants of the Hastings Reservation, Central Coastal California: A Comparison. Biological Conservation. 71:115-123.

Lemmon, R.E. Forest Densiometers, 5733 SE Cornell Drive, Bartlesville, OK 74006.

Lonsdale, W.M., and A.M. Lane. 1994. Tourist vehicles as vectors of weed seeds in Kakadu National Park, Northern Australia. Biological Conservation. 69:277-283.

Luken, J.O., A.C. Hinton, and D.G. Baker. 1991. Forest edges associated with powerline corridors and implications for corridor siting. Landscape and Urban Planning. 20: 315-324.

MacArthur, R.H., and E.O. Wilson. The Theory of Island Biogeography. Princeton, NJ: Princeton University Press; 1967.

Magee, T.K., T.L. Ernst, M.E. Kentula, and K.A. Dwire. 1999. Floristic Comparison of Freshwater Wetlands in an Urbanizing Environment. Wetlands. 19:517-534.

Meekins, J.F., and B.C. McCarthy. 2001. Effect of Environmental Variation on the Invasive Success of a Nonindigenous Forest Herb. Ecological Applications. 11:13361348 .

Metro Regional Government, 2003. http://www.metroregion.org/article.cfm?articleid=266. 
Murcia, C. 1995. Edge Effects in Fragmented Forests: Implications for Conservation. Trends in Ecology and Evolution. 10:58-62.

Murphy, D.D., and B.A. Wilcox. 1986. On Island Biogeography and Conservation. Oikos. 47(3): 385-387.

Nuzzo, V. Element Stewardship Abstract for Alliaria petiolata. The Nature Conservancy, Wildland Invasive Species Program: University of California, Davis: 2000 .

NVCS- National Vegetation Classification System. 2003.

Biology.usgs.gov/npsveg/classification/index.html

O’Neil, M.P., and J.A. Yeakley. 2000. Biogeographic Variation and Riparian Plant Species Diversity in an Urbanizing Oregon Basin. International Conference on Riparian Ecology and Management in Multi-Land Use Watersheds. American Water Resources Association.

Oregon Department of Agriculture (2003), Noxious Weed Control Program, http://oda.state.or.us/Plant/weed control/ProgramInfo.html

Oregon Department of Fish and Wildlife. 1997. Sensitive Species List. www.dfw.state.or.us/odfwhtml/infocntrwild/diversity/senspecies.pdf

Parendes, L.A., and J.A. Jones. 2000. Role of Light Availability and Dispersal in Exotic Plant Invasion along Roads and Streams in the H.J. Andrews Experimental Forest, Oregon. Conservation Biology. 14:64-75.

Perry, D.A. Forest Ecosystems. p.127. Baltimore, MD.: The Johns Hopkins University Press; 1994.

Pojar, J. and A. MacKinnon. Plants of the Pacific Northwest Coast. Renton, WA: Lone Fir Press; 1994.

Pysek, P., V. Jarosik, and T. Kucera. 2002. Patterns of Invasion in Temperate Nature Reserves. Biological Conservation. 104: 13-24.

Quinn, G.P., and M.J. Keough. Experimental Design and Data Analysis for Biologists. Cambridge, UK: Cambridge University Press; 2002.

Quinn, J.F., and S.P. Harrison. 1988. Effects of Habitat Fragmentation and Isolation on Species Richness: Evidence from Biogeographic Patterns. Oecologia. 75: 132-140. 
Rockey, C.C.D. 2004. Climate of Portland Oregon. National Weather Forecast Office, Portland, OR. www.wrh.noaa.gov/pqr/pdxclimate/PG1 TO4.html

SAS Institute Inc., SAS/STAT User's Guide, Version 6. Vol. 2. Cary, NC: SAS Institute Inc.; 1989.

Saunders, D.A., R.J. Hobbs, C.R. Margules. 1991. Biological Consequences of Ecosystem Fragmentation: A Review. Conservation Biology. 5:18-32.

Schoonmaker P., and A. McKee. 1988. Species composition and diversity during secondary succession of conifer forests in the Western Cascade Mountains of Oregon. Forest Science. 34:960-979.

Sharp, M.M. 2002. Effects of physical soil properties on the coverage of native and non-native plants in urban riparian areas. Unpublished Master's thesis. Portland State University.

Simberloff, D., D.C. Schmitz, and T.C. Brown. Strangers in paradise : impact and management of nonindigenous species in Florida. Washington, D.C.: Island Press; 1997.

Soule, M.E., A.C. Alberts, and D.T. Bolger. 1992. The Effects of Habitat Fragmentation on Chaparral Plants and Vertebrates. Oikos. 63:39-47.

Spinks, K. 2003. Personal communication. Natural Resource Technician- Tualatin Hills Park \& Recreation District.

U.S. Bureau of the Census, 1990 \& 200 Census of Population and Housing for Portland, OR-Vancouver, WA area.

Vogelmann, J.E. 1995. Assessment of Forest Fragmentation in Southern New England Using Remote Sensing and Geographic Information Systems Technology. Conservation Biology. 9:439-449.

Weathers, K.C., M.L. Cadenasso, and S.T.A. Pickett. 2001. Forest Edges as Nutrient and Pollutant Concentrators: Potential Synergisms between Fragmentation, Forest Canopies, and the Atmosphere. Conservation Biology. 15(6): 1506-1514.

Whitney, G.G. and J.R. Runkle. 1981. Edge Versus Age Effects in the Development of a Beech-Maple Forest. Oikos. 37:377-381.

Young, A., and N. Mitchell. 1994. Microclimate And Vegetation Edge Effects in a Fragmented Podocarp-Broadleaf Forest in New Zealand. Biological Conservation. 67:63-72. 
Zuidema, P.A., Sayer, J.A., Dijkman, W. 1996. Forest Fragmentation and Biodiversity: the Case for Intermediate Sized Conservation Areas. Environmental Conservation. 23:290-297. 
APPENDIX A. Plant species recorded at each site. 
A. Plant species and the total length (in meters) of each measured at sites with field edges. Length measurements were used to calculate cover. Bold Latin names indicate exotic species.

\begin{tabular}{|c|c|c|c|c|c|c|c|c|c|}
\hline & site ná & mes & & & & & & & \\
\hline Latin name & 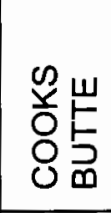 & 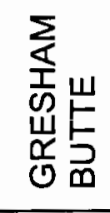 & 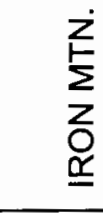 & 总崖 & $\sum_{\underset{\mathrm{J}}{\mathrm{U}}}^{\mathrm{W}}$ & 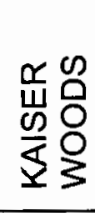 & 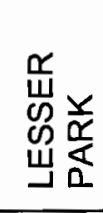 & 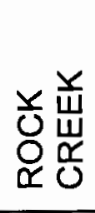 & 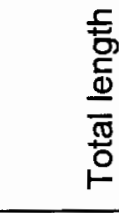 \\
\hline Abies grandis & & & & & & 5.3 & & & 5.3 \\
\hline Acer circinatum & 43.66 & & & & 29.42 & 1.1 & 1.68 & 2.9 & 78.76 \\
\hline $\begin{array}{l}\text { Acer } \\
\text { macrophyllum }\end{array}$ & & 35.4 & 56.08 & 8.75 & 49.28 & 4.95 & 50.62 & & 205.08 \\
\hline $\begin{array}{l}\text { Adenocaulon } \\
\text { bicolor }\end{array}$ & & 10.8 & 2.3 & & 34.75 & 2.1 & 10.1 & 12 & 72.05 \\
\hline Alliaria petiolata & & & 2.86 & 15.53 & & 2.7 & & 8.35 & 29.44 \\
\hline Alnus rubra & & & 8.16 & & & & & & 8.16 \\
\hline $\begin{array}{l}\text { Amelanchier } \\
\text { alnifolia }\end{array}$ & & & & & & & & 1.31 & 1.31 \\
\hline $\begin{array}{l}\text { Arbutus } \\
\text { menziesii }\end{array}$ & & & & & & & 7.61 & & 7.61 \\
\hline $\begin{array}{l}\text { Athyrium filix- } \\
\text { femina }\end{array}$ & & & & & & 0.24 & & & 0.24 \\
\hline Betula pendula & & 0.48 & & & & & & 2.75 & 3.23 \\
\hline $\begin{array}{l}\text { Claytonia } \\
\text { sibirica }\end{array}$ & & 1.27 & & & 0.02 & & & & 1.29 \\
\hline $\begin{array}{l}\text { Clematis } \\
\text { ligusticifolia }\end{array}$ & & & & & & & & & 0 \\
\hline Clematis vitalba & & & & & & 0.17 & & & 0.17 \\
\hline $\begin{array}{l}\text { Convolvulus } \\
\text { arvensis }\end{array}$ & & & & 0.35 & & & & & 0.35 \\
\hline Cornus nuttallii & & & & & & & 1.14 & & 1.14 \\
\hline Cornus sericea & 17.58 & 12.34 & 25.33 & 6.81 & 18.73 & 19.59 & 22.35 & 30.6 & 153.33 \\
\hline Corylus cornuta & & 0.12 & & 0.3 & 0.47 & & & & 0.89 \\
\hline $\begin{array}{l}\text { Crataegus } \\
\text { douglasii }\end{array}$ & & . & 1.23 & & & & & & 1.23 \\
\hline $\begin{array}{l}\text { Crataegus } \\
\text { monogyna }\end{array}$ & & & & & & 1.75 & & & 1.75 \\
\hline Crepis setosa & & & & & & 0.86 & 0.4 & & 1.26 \\
\hline Daucus carota & & & & & & & 0.45 & & 0.45 \\
\hline $\begin{array}{l}\text { Disporum } \\
\text { hookeri }\end{array}$ & & & 0.2 & 2.03 & & & & & 2.23 \\
\hline $\begin{array}{l}\text { Equisetum } \\
\text { arvense }\end{array}$ & & 1.89 & & & 0.2 & & & & 2.09 \\
\hline $\begin{array}{l}\text { Euonymus } \\
\text { occidentalis }\end{array}$ & & & & 0.25 & & & & & 0.25 \\
\hline
\end{tabular}




\begin{tabular}{|c|c|c|c|c|c|c|c|c|c|}
\hline $\begin{array}{l}\text { Fragaria } \\
\text { chilensis }\end{array}$ & & & & & & 0.01 & & & 0.01 \\
\hline Fraxinus latifolia & & & & & & & 0.57 & & 0.57 \\
\hline Galium aparine & & 0.05 & & & & 41.38 & & 8.76 & 50.19 \\
\hline Galium triflorum & & & 1.79 & & & & & & 1.79 \\
\hline $\begin{array}{l}\text { Gaultheria } \\
\text { shallon }\end{array}$ & 0.77 & & 0.45 & 9.86 & 0.44 & 2.74 & 4.48 & & 18.74 \\
\hline $\begin{array}{l}\text { Geranium } \\
\text { robertianum }\end{array}$ & & & 10.77 & & & 8.96 & & & 19.73 \\
\hline $\begin{array}{l}\text { Geum } \\
\text { macrophyllum }\end{array}$ & & 5.2 & & & & & & 0.5 & 5.7 \\
\hline Hedera helix & 2.33 & & & & & & 0.95 & 0.3 & 3.58 \\
\hline $\begin{array}{l}\text { Holodiscus } \\
\text { discolor }\end{array}$ & & & & & & 0.02 & & & 0.02 \\
\hline $\begin{array}{l}\text { Hydrophyllum } \\
\text { tenuipes }\end{array}$ & & & & & 0.1 & & & & 0.1 \\
\hline Ilex aquifolium & & & & & & & 2.03 & & 2.03 \\
\hline Lactuca muralis & & & & & & & 0.5 & & 0.5 \\
\hline $\begin{array}{l}\text { Lapsana } \\
\text { communis }\end{array}$ & 79.73 & & 83.03 & 49.77 & & & 4.59 & & 217.12 \\
\hline $\begin{array}{l}\text { Lathyrus } \\
\text { sylvestrus }\end{array}$ & & & 2.4 & 0.85 & 0.59 & 6.4 & & & 10.24 \\
\hline Lonicera ciliosa & & 0.01 & & & & & & & 0.01 \\
\hline $\begin{array}{l}\text { Mahonia } \\
\text { aquifolium }\end{array}$ & & & & 0.5 & & & 1.9 & & 2.4 \\
\hline $\begin{array}{l}\text { Mahonia } \\
\text { nervosa }\end{array}$ & & & & & 2.17 & 0.85 & 7.66 & & 10.68 \\
\hline Malus fusca & & 4.9 & & & 10.63 & & & 0.2 & 15.73 \\
\hline $\begin{array}{l}\text { Medicago } \\
\text { lupulina }\end{array}$ & & & & & & & & 0.2 & 0.2 \\
\hline $\begin{array}{l}\text { Oemleria } \\
\text { cerasiformis }\end{array}$ & 1.29 & & & 0.4 & & & 9.52 & 0.01 & 11.22 \\
\hline $\begin{array}{l}\text { Polystichum } \\
\text { munitum }\end{array}$ & & & & & & & 0.6 & & 0.6 \\
\hline Prunus avium & & & & & & 0.1 & 2.62 & & 2.72 \\
\hline $\begin{array}{l}\text { Prunus } \\
\text { emarginata }\end{array}$ & & & & & & 0.23 & & & 0.23 \\
\hline $\begin{array}{l}\text { Prunus } \\
\text { laurocerasus }\end{array}$ & & & 0.43 & 2.9 & 0.8 & & & 0.11 & 4.24 \\
\hline Prunus sp. & & & & & & 0.17 & 23.59 & 0.01 & 23.77 \\
\hline $\begin{array}{l}\text { Pseudotsuga } \\
\text { menziesii }\end{array}$ & & & & & & & 0.4 & & 0.4 \\
\hline $\begin{array}{l}\text { Pteridium } \\
\text { aquilinum }\end{array}$ & 1.22 & & 3.3 & 4.87 & 3.94 & 0.7 & & 21.88 & 35.91 \\
\hline Ribes lacustre & & & & & & 10.55 & & 0.5 & 11.05 \\
\hline $\begin{array}{l}\text { Rosa } \\
\text { gymnocarpa }\end{array}$ & & & 1.27 & 0.09 & & & & & 1.36 \\
\hline
\end{tabular}




\begin{tabular}{|c|c|c|c|c|c|c|c|c|c|}
\hline Rosa pisocarpa & 14.46 & 35.27 & 30.18 & 4.83 & 9.1 & 13.62 & 9.8 & 14.75 & 132.01 \\
\hline Rubus discolor & 60.5 & 43.65 & 38.63 & 97.9 & & 31.95 & & 21.65 & 294.28 \\
\hline $\begin{array}{l}\text { Rubus } \\
\text { leucodermis }\end{array}$ & & 0.29 & 0.68 & & & 2.05 & 0.36 & 0.29 & 3.67 \\
\hline $\begin{array}{l}\text { Rubus } \\
\text { parviflorus }\end{array}$ & & & & & & 3 & & 11.1 & 14.1 \\
\hline $\begin{array}{l}\text { Rubus } \\
\text { spectabilis }\end{array}$ & & & & & & 0.95 & & 10.21 & 11.16 \\
\hline Rubus ursinus & & & & & & & & 0.26 & 0.26 \\
\hline Rumex crispus & 15.36 & & & & 2.65 & 1.65 & 16.25 & 10.3 & 46.21 \\
\hline $\begin{array}{l}\text { Salix } \\
\text { scouleriana }\end{array}$ & & & & & & 0.62 & & & 0.62 \\
\hline $\begin{array}{l}\text { Sambucus } \\
\text { cerulea }\end{array}$ & & & 0.01 & 1.67 & & 4.47 & & & 6.15 \\
\hline $\begin{array}{l}\text { Sambucus } \\
\text { racemosa }\end{array}$ & & & & & & 3.36 & & & 3.36 \\
\hline $\begin{array}{l}\text { Smilacina } \\
\text { racemosa }\end{array}$ & 28.1 & & & & & & & & 28.1 \\
\hline $\begin{array}{l}\text { Sorbus } \\
\text { scopulina }\end{array}$ & & & & & & & 0.1 & & 0.1 \\
\hline $\begin{array}{l}\text { Symphoricarpos } \\
\text { albus }\end{array}$ & & & 2.77 & & & & 4.2 & & 6.97 \\
\hline $\begin{array}{l}\text { Taraxacum } \\
\text { officinale }\end{array}$ & & & & & & 0.18 & & & 0.18 \\
\hline Taraxacum sp. & & & & & 0.03 & 0.35 & & 0.15 & 0.53 \\
\hline $\begin{array}{l}\text { Tellima } \\
\text { grandiflora }\end{array}$ & 18.34 & 9.54 & 1.97 & 29.03 & 4.62 & 13.32 & 7.42 & 4 & 88.24 \\
\hline Thuja plicata & & & & & & 6.3 & & & 6.3 \\
\hline $\begin{array}{l}\text { Tolmiea } \\
\text { menziesii }\end{array}$ & & & 1.57 & & & & & & 1.57 \\
\hline $\begin{array}{l}\text { Toxicodendron } \\
\text { diversilobum }\end{array}$ & & 2.98 & & & & & & & 2.98 \\
\hline $\begin{array}{l}\text { Trientalis } \\
\text { borealis }\end{array}$ & & & & & & & 9.1 & & 9.1 \\
\hline Trillium ovatum & & & & 0.1 & & & & & 0.1 \\
\hline $\begin{array}{l}\text { Tsuga } \\
\text { heterophylla }\end{array}$ & & & & & & & 6.8 & & 6.8 \\
\hline Urtica dioica & & & & & & 0.75 & & & 0.75 \\
\hline $\begin{array}{l}\text { Vaccinium } \\
\text { parvifolium }\end{array}$ & & & & & & & 0.55 & & 0.55 \\
\hline $\begin{array}{l}\text { Vancouveria } \\
\text { hexandra }\end{array}$ & & & & & & & 0.1 & & 0.1 \\
\hline Vicia americana & & & & 0.55 & & & & & 0.55 \\
\hline Vicia hirsuta & & 1.91 & 0.16 & 14.18 & 12.69 & 9.92 & 0.65 & 35.54 & 75.05 \\
\hline Viola glabella & & & & & & 0.35 & & & 0.35 \\
\hline $\begin{array}{l}\text { Rhamnus } \\
\text { purshiana }\end{array}$ & & & & 0.03 & 0.09 & & & & 0.12 \\
\hline
\end{tabular}


B. Plant species and the total length (in meters) of each measured at sites with residential edges. Length measurements were used to calculate cover. Bold Latin names indicate exoitc species.

\begin{tabular}{|c|c|c|c|c|c|c|c|c|c|}
\hline 2.2 & site na & nes & & & & & & & \\
\hline Latin names & 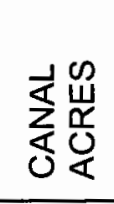 & 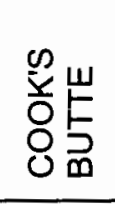 & 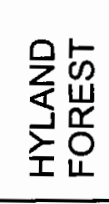 & 岂屴 & 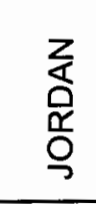 & $\begin{array}{l}\text { 品号 } \\
\text { 员 } \\
\frac{8}{5}\end{array}$ & 䒺占 & 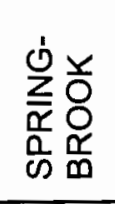 & 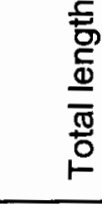 \\
\hline Acer circinatum & & & & 15.25 & 6.09 & 4.74 & 15.23 & & 41.31 \\
\hline $\begin{array}{l}\text { Acer } \\
\text { macrophyllum }\end{array}$ & 17.45 & 84.24 & 55 & 25.6 & 61.5 & 24.74 & & 84.83 & $\begin{array}{r}353.3 \\
6 \\
\end{array}$ \\
\hline Acer negundo & & & & & & & & 1.6 & 1.6 \\
\hline Alnus rubra & 40.65 & & & 32.7 & & & & & 73.35 \\
\hline $\begin{array}{l}\text { Amelanchier } \\
\text { alnifolia }\end{array}$ & & 0.2 & & & & 2.48 & & & 2.68 \\
\hline $\begin{array}{l}\text { Aucuba } \\
\text { japonica }\end{array}$ & & & & & & & & 1.75 & 1.75 \\
\hline Betula pendula & & & 2.45 & & & & & & 2.45 \\
\hline $\begin{array}{l}\text { Carex } \\
\text { deweyana }\end{array}$ & & & & & 0.93 & & & & 0.93 \\
\hline $\begin{array}{l}\text { Carex } \\
\text { hendersonii }\end{array}$ & & & 0.2 & & 0.04 & & & & 0.24 \\
\hline Carex obnupta & & & & & & 16.3 & & & 16.3 \\
\hline Circaea alpina & & & 0.56 & & & & & & 0.56 \\
\hline $\begin{array}{l}\text { Clinopodium } \\
\text { douglasii }\end{array}$ & & & & 0.1 & & & & & 0.1 \\
\hline $\begin{array}{l}\text { Claytonia } \\
\text { sibirica }\end{array}$ & & & & 2.47 & & & & & 2.47 \\
\hline $\begin{array}{l}\text { Convolvulus } \\
\text { arvensis }\end{array}$ & & & & & & & & 5.33 & 5.33 \\
\hline Corylus cornuta & 12.84 & 21.6 & 45.67 & 28.5 & 4.85 & 3.8 & 38.92 & 22.74 & $\begin{array}{r}178.9 \\
2\end{array}$ \\
\hline Cornus nuttallii & & & 7.15 & & & & 0.65 & & 7.8 \\
\hline $\begin{array}{l}\text { Crataegus } \\
\text { monogyna }\end{array}$ & 2.27 & 3.49 & 13.84 & & 0.94 & & & & 20.54 \\
\hline Daucus carota & & & & & 0.19 & & & & 0.19 \\
\hline $\begin{array}{l}\text { Disporum } \\
\text { hookeri }\end{array}$ & & 2.28 & & & & & 0.08 & & 2.36 \\
\hline $\begin{array}{l}\text { Dryopteris } \\
\text { expansa }\end{array}$ & & & 1.25 & & & & & & 1.25 \\
\hline $\begin{array}{l}\text { Epilobium } \\
\text { ciliatum }\end{array}$ & & & & 1.72 & & & & & 1.72 \\
\hline $\begin{array}{l}\text { Euphorbia } \\
\text { lathyris }\end{array}$ & & & & & 0.49 & & & & 0.49 \\
\hline $\begin{array}{l}\text { Euonymus } \\
\text { occidentalis }\end{array}$ & & & & & & & 1.47 & & 1.47 \\
\hline
\end{tabular}




\begin{tabular}{|c|c|c|c|c|c|c|c|c|c|}
\hline $\begin{array}{l}\text { Fraxinus } \\
\text { latifolia }\end{array}$ & 18.5 & & & & & 45.1 & 0.55 & & 64.15 \\
\hline $\begin{array}{l}\text { Galium } \\
\text { triflorum }\end{array}$ & & & & 8.73 & & 1.15 & 0.06 & & 9.94 \\
\hline Galium aparine & & 0.01 & 0.67 & & 11.61 & & & & 12.29 \\
\hline $\begin{array}{l}\text { Gaultheria } \\
\text { shallon }\end{array}$ & & & 1.95 & & & 3.4 & & & 5.35 \\
\hline Galium trifidum & 1.11 & & & & & & 0.77 & & 1.88 \\
\hline $\begin{array}{l}\text { Geum } \\
\text { macrophyllum }\end{array}$ & 0.39 & & & & 0.04 & & & 0.71 & 1.14 \\
\hline $\begin{array}{l}\text { Geranium } \\
\text { robertianum }\end{array}$ & & 27.61 & 2.06 & 1 & & & & & 30.67 \\
\hline Hedera helix & 10.61 & 25.88 & 63.44 & & 7.87 & 2.32 & 45.71 & 50.46 & $\begin{array}{r}206.2 \\
a\end{array}$ \\
\hline $\begin{array}{l}\text { Holodiscus } \\
\text { discolor }\end{array}$ & & 3.8 & 1.94 & & & 2.46 & 0.28 & 3 & 11.48 \\
\hline $\begin{array}{l}\text { Hypericum } \\
\text { perforatum }\end{array}$ & & & & & 0.52 & & & & 0.52 \\
\hline $\begin{array}{l}\text { Hydrophyllum } \\
\text { tenuipes }\end{array}$ & 1.36 & & & 1.62 & 1.66 & & & & 4.64 \\
\hline llex aquifolium & & & 4.88 & & & & 2.38 & 4.32 & 11.58 \\
\hline Jugulans sp. & & & & & 0.1 & & & & 0.1 \\
\hline $\begin{array}{l}\text { Lapsana } \\
\text { communis }\end{array}$ & & & & 0.59 & 0.41 & & & & 1 \\
\hline Lactuca muralis & & 0.33 & 0.07 & & & & & & 0.4 \\
\hline $\begin{array}{l}\text { Leucanthemum } \\
\text { vulgare }\end{array}$ & & & & & 0.86 & & & & 0.86 \\
\hline Lonicera ciliosa & & & & & & 3.41 & & & 3.41 \\
\hline Lunaria sp. & & & & & 0.06 & & & & 0.06 \\
\hline $\begin{array}{l}\text { Mahonia } \\
\text { aquifolium }\end{array}$ & & & 1.35 & & 0.01 & & & & 1.36 \\
\hline $\begin{array}{l}\text { Mahonia } \\
\text { nervosa }\end{array}$ & & 0.04 & 2.65 & & & 0.02 & 11.09 & & 13.8 \\
\hline $\begin{array}{l}\text { Oemleria } \\
\text { cerasiformis }\end{array}$ & 0.15 & & & 5.02 & 1.79 & & 4.52 & 1.32 & 12.8 \\
\hline $\begin{array}{l}\text { Physocarpus } \\
\text { capitatus }\end{array}$ & 1.8 & & & & & 16.48 & & & 18.28 \\
\hline $\begin{array}{l}\text { Polypodium } \\
\text { glycyrrhiza }\end{array}$ & & 0.9 & & & & & & & 0.9 \\
\hline $\begin{array}{l}\text { Polystichum } \\
\text { munitum }\end{array}$ & 7.26 & 9.38 & 38.08 & 8.75 & 12.16 & 28.16 & 12.33 & 22.15 & $\begin{array}{r}138.2 \\
7 \\
\end{array}$ \\
\hline Prunus avium & 28 & 41.5 & 1.45 & & 0.05 & & 4.75 & 16.08 & 91.83 \\
\hline $\begin{array}{l}\text { Prunus } \\
\text { laurocerasus }\end{array}$ & 0.66 & 1.85 & & & & & 1.2 & 1.33 & 5.04 \\
\hline $\begin{array}{l}\text { Pseudotsuga } \\
\text { menziesii }\end{array}$ & 4.8 & 34.01 & 55.5 & & 52.7 & 18.17 & 90 & 2.45 & $\begin{array}{r}257.6 \\
3 \\
\end{array}$ \\
\hline $\begin{array}{l}\text { Pteridium } \\
\text { aquilinum }\end{array}$ & & & 0.26 & & 0.41 & & 7.54 & 0.2 & 8.41 \\
\hline Quercus & & & & & & 4.85 & & & 4.85 \\
\hline
\end{tabular}




\begin{tabular}{|c|c|c|c|c|c|c|c|c|c|}
\hline garryana & & & & & & & & & \\
\hline $\begin{array}{l}\text { Rhamnus } \\
\text { purshiana }\end{array}$ & & & & & & 0.21 & & & 0.21 \\
\hline $\begin{array}{l}\text { Rosa } \\
\text { gymnocarpa }\end{array}$ & & & 0.52 & & & 0.22 & & & 0.74 \\
\hline Rosa sp. & & 2.03 & & & & & & & 2.03 \\
\hline Rosa nutkana & 6.47 & & & & & & & & 6.47 \\
\hline Rubus discolor & 50.32 & 0.55 & 8.91 & 28.9 & 6.1 & & 2.1 & 0.2 & 97.08 \\
\hline $\begin{array}{l}\text { Rubus } \\
\text { parviflorus }\end{array}$ & 4.6 & 5.86 & 3.48 & & 29.82 & & 8.76 & 3.51 & 56.03 \\
\hline Rubus ursinus & 32.37 & 29.47 & 9.65 & 2.56 & & 40.98 & 17.57 & 15.93 & $\begin{array}{r}148.5 \\
3 \\
\end{array}$ \\
\hline $\begin{array}{l}\text { Sambucus } \\
\text { cerulea }\end{array}$ & & & 0.3 & & & & & & 0.3 \\
\hline $\begin{array}{l}\text { Sambucus } \\
\text { racemosa }\end{array}$ & 4.57 & 1.35 & 3.1 & & & & & & 9.02 \\
\hline $\begin{array}{l}\text { Smilacina } \\
\text { racemosa }\end{array}$ & & & & & & 0.51 & & & 0.51 \\
\hline Smil. stellata & & & & & 0.02 & & & & 0.02 \\
\hline $\begin{array}{l}\text { Sorbus } \\
\text { aucuparia }\end{array}$ & & & & & & & & 0.1 & 0.1 \\
\hline Sor.scopulina & & & & & & & 1.9 & & 1.9 \\
\hline $\begin{array}{l}\text { unknown } \\
\text { species } 1\end{array}$ & & & & & & & 0.17 & & 0.17 \\
\hline $\begin{array}{l}\text { unknown } \\
\text { species } 2\end{array}$ & & & & & 0.16 & & & & 0.16 \\
\hline $\begin{array}{l}\text { Symphori- } \\
\text { carpos albus }\end{array}$ & 2.41 & 0.07 & & 9.75 & 8.07 & 5.67 & 1.44 & 5.15 & 32.56 \\
\hline Taxus brevifolia & & & & & & 4.25 & & & 4.25 \\
\hline $\begin{array}{l}\text { Tellima } \\
\text { grandiflora }\end{array}$ & & 0.05 & & 0.35 & 1.14 & & & & 1.54 \\
\hline Thuja plicata & & & & & 8.4 & & & & 8.4 \\
\hline $\begin{array}{l}\text { Trientalis } \\
\text { borealis }\end{array}$ & & & & & & 0.12 & & & 0.12 \\
\hline Trillium avatum & 0.24 & 0.09 & 0.38 & & & & & & 0.71 \\
\hline $\begin{array}{l}\text { Tsuga } \\
\text { heterophylla }\end{array}$ & & & & & & & & 4.98 & 4.98 \\
\hline Urtica dioica & 0.01 & & & 6.38 & 4.28 & 1.2 & & & 11.87 \\
\hline $\begin{array}{l}\text { Vancouveria } \\
\text { hexandra }\end{array}$ & & 7.63 & 0.69 & & & & 25.66 & & 33.98 \\
\hline $\begin{array}{l}\text { Vaccinium } \\
\text { parvifolium }\end{array}$ & & & & & & 2.3 & & & 2.3 \\
\hline $\begin{array}{l}\text { Vicia } \\
\text { americana }\end{array}$ & & 0.01 & & & & & & & 0.01 \\
\hline Viola glabella & & 0.2 & & & 0.06 & 0.1 & & & 0.36 \\
\hline Vicia sativa & & & & 1.3 & & & & & 1.3 \\
\hline
\end{tabular}


C. Plant species and the total length (in meters) of each measured at sites with road edges. Length measurements were used to calculate cover. Bold Latin names indicate exoitc species.

\begin{tabular}{|c|c|c|c|c|c|c|c|c|c|}
\hline & site na & nes & & & & & & & \\
\hline Latine names & 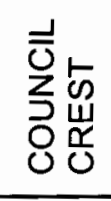 & 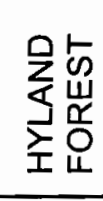 & $\underset{\mathscr{T}}{\stackrel{\mathscr{I}}{\longrightarrow}}$ & $\frac{\frac{\$}{\alpha}}{\frac{\delta}{\alpha}}$ & 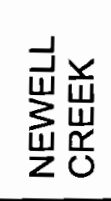 & 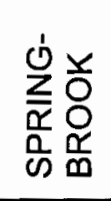 & 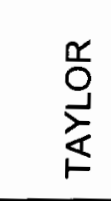 & 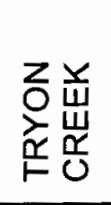 & 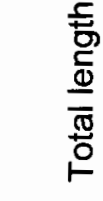 \\
\hline Abies grandis & 1.7 & 1.63 & & & & & & & 3.33 \\
\hline Acer circinatum & 23.5 & & 83.12 & 15.23 & 7.75 & & & & 129.6 \\
\hline $\begin{array}{l}\text { Acer } \\
\text { macrophyllum }\end{array}$ & 94.1 & & 4.15 & 27.02 & 32.04 & 72.03 & 79.22 & 69.87 & $\begin{array}{r}378.4 \\
3\end{array}$ \\
\hline $\begin{array}{l}\text { Adenocaulon } \\
\text { bicolor }\end{array}$ & 0.45 & & & & & & & & 0.45 \\
\hline Alliaria petiolata & & & & & & 28.18 & & 0.31 & 28.49 \\
\hline Alnus rubra & & & 60.95 & & 7.1 & & 4 & 14.9 & 86.95 \\
\hline $\begin{array}{l}\text { Amelanchier } \\
\text { alnifolia }\end{array}$ & & 15.97 & & 18.45 & & 9.85 & 13.99 & & 58.26 \\
\hline $\begin{array}{l}\text { Arbutus } \\
\text { menziesii }\end{array}$ & & & & & & & & & 0 \\
\hline $\begin{array}{l}\text { Athyrium filix- } \\
\text { femina }\end{array}$ & & & 0.75 & & & & & & 0.75 \\
\hline Betula pendula & 9.01 & & & & & & & & 9.01 \\
\hline $\begin{array}{l}\text { Clematis } \\
\text { ligusticifolia }\end{array}$ & & & & & & 4.4 & 0.5 & & 4.9 \\
\hline $\begin{array}{l}\text { Claytonia } \\
\text { sibirica }\end{array}$ & & & 0.37 & & & & & 0.35 & 0.72 \\
\hline Clematis vitalba & & & 2.85 & & & 1.89 & & & $\overline{4.74}$ \\
\hline $\begin{array}{l}\text { Convolvulus } \\
\text { arvensis }\end{array}$ & & & & & & & & 14.39 & 14.39 \\
\hline Corylus cornuta & 5.87 & 60.6 & & 41.23 & 19.08 & 14.22 & 4.29 & & $\begin{array}{r}145.2 \\
\end{array}$ \\
\hline Cornus nuttalliii & & 13.57 & & & & & & & 13.57 \\
\hline Cornus sericea & & & & & & 5.47 & & & 5.47 \\
\hline $\begin{array}{l}\text { Crataegus } \\
\text { douglasii }\end{array}$ & & & & & & 6.8 & & & 6.8 \\
\hline $\begin{array}{l}\text { Crataegus } \\
\text { monogyna }\end{array}$ & & & & & & & 9.43 & & 9.43 \\
\hline Crepis setosa & & & & & 0.22 & & & & 0.22 \\
\hline Daucus carota & & & & & 0.2 & & 0.14 & & 0.34 \\
\hline $\begin{array}{l}\text { Disporum } \\
\text { hookeri }\end{array}$ & & & 0.24 & & & & & & 0.24 \\
\hline $\begin{array}{l}\text { Equisetum } \\
\text { arvense }\end{array}$ & & & 4.43 & & & & & & 4.43 \\
\hline $\begin{array}{l}\text { Euonymus } \\
\text { occidentalis }\end{array}$ & & & & & & 2.34 & & & 2.34 \\
\hline Fragaria & 1.2 & & & & & & & & 1.2 \\
\hline
\end{tabular}




\begin{tabular}{|c|c|c|c|c|c|c|c|c|c|}
\hline chilensis & & & & & & & & & \\
\hline Fraxinus latifolia & & & & & & & 16.42 & 5 & 21.42 \\
\hline Galium triflorum & & & 0.3 & & & & & & 0.3 \\
\hline Galium aparine & & 0.2 & & 0.01 & 0.97 & & & & 1.18 \\
\hline $\begin{array}{l}\text { Gaultheria } \\
\text { shallon }\end{array}$ & 21.68 & 5.4 & & & 0.13 & & & & 27.21 \\
\hline $\begin{array}{l}\text { Geum } \\
\text { macrophyllum }\end{array}$ & 0.8 & & & & & & & & 0.8 \\
\hline $\begin{array}{l}\text { Geranium } \\
\text { robertianum }\end{array}$ & 0.9 & 1.75 & 0.32 & 0.1 & & 0.32 & 0.37 & 2.17 & 5.93 \\
\hline Hedera helix & 0.47 & 3.98 & 2.71 & 0.2 & & 0.75 & 0.3 & 87.09 & 95.5 \\
\hline $\begin{array}{l}\text { Holodiscus } \\
\text { discolor }\end{array}$ & & 0.91 & & 0.42 & 4.55 & & & & 5.88 \\
\hline $\begin{array}{l}\text { Hydrophyllum } \\
\text { tenuipes }\end{array}$ & 0.04 & & 0.73 & & & 1.51 & & 1.43 & 3.71 \\
\hline llex aquifolium & & & & & 0.3 & 0.55 & 2.55 & 4.91 & 8.31 \\
\hline $\begin{array}{l}\text { Lapsana } \\
\text { communis }\end{array}$ & 0.42 & 0.15 & 0.03 & 0.55 & & & 0.15 & & 1.3 \\
\hline Lactuca muralis & & 0.45 & & & & & & & 0.45 \\
\hline $\begin{array}{l}\text { Lathyrus } \\
\text { sylvestrus }\end{array}$ & & & & & 0.06 & & & & 0.06 \\
\hline Lonicera ciliosa & & & & 0.07 & & & & & 0.07 \\
\hline $\begin{array}{l}\text { Mahonia } \\
\text { aquifolium }\end{array}$ & 0.57 & 8.26 & & 1.14 & & & & 16.1 & 26.07 \\
\hline Malus fusca & & & & 6.96 & & & & & 6.96 \\
\hline $\begin{array}{l}\text { Mahonia } \\
\text { nervosa }\end{array}$ & 7 & 2.42 & 5.13 & 4.97 & & & & & 19.52 \\
\hline $\begin{array}{l}\text { Medicago } \\
\text { lupulina }\end{array}$ & & & & & 0.06 & & & & 0.06 \\
\hline $\begin{array}{l}\text { Oemleria } \\
\text { cerasiformis }\end{array}$ & 7.47 & & 10.32 & 0.16 & & 24.11 & & 1.04 & 43.1 \\
\hline $\begin{array}{l}\text { Polystichum } \\
\text { munitum }\end{array}$ & 28.3 & 27.63 & 24.37 & 12.26 & 39.93 & 11.86 & 9.04 & 7.52 & $\begin{array}{r}160.9 \\
1\end{array}$ \\
\hline Prunus avium & 0.15 & 2.76 & & 11.84 & & & & 1.15 & 15.9 \\
\hline $\begin{array}{l}\text { Prunus } \\
\text { emarginata }\end{array}$ & 18.43 & & & & & & & & 18.43 \\
\hline $\begin{array}{l}\text { Prunus } \\
\text { laurocerasus }\end{array}$ & & & & & & 5.1 & & & 5.1 \\
\hline Prunus sp. & & & & & 6.5 & & & & 6.5 \\
\hline $\begin{array}{l}\text { Pseudotsuga } \\
\text { menziesii }\end{array}$ & 57.5 & 70.1 & 4.3 & 61.67 & 24.22 & & 6.58 & 53.5 & $\begin{array}{r}277.8 \\
7\end{array}$ \\
\hline $\begin{array}{l}\text { Pteridium } \\
\text { aquilinum }\end{array}$ & & 1.29 & & 0.01 & 2.51 & 2.78 & & 6.1 & 12.69 \\
\hline $\begin{array}{l}\text { Rhamnus } \\
\text { purshiana }\end{array}$ & & 5.4 & & & & & 0.75 & & 6.15 \\
\hline Ribes lacustre & & & & & 0.1 & & & & 0.1 \\
\hline $\begin{array}{l}\text { Rosa } \\
\text { gymnocarpa }\end{array}$ & 0.93 & 6.52 & & & & & 0.65 & & 8.1 \\
\hline Rosa pisocarpa & & & & & & & 0.97 & & 0.97 \\
\hline Rumex crispus & & & & & & & & & 0 \\
\hline
\end{tabular}




\begin{tabular}{|c|c|c|c|c|c|c|c|c|c|}
\hline Rubus discolor & 0.17 & 17.23 & & 0.15 & 9.9 & 21.1 & 43.94 & 6.81 & 99.3 \\
\hline $\begin{array}{l}\text { Rubus } \\
\text { leucodermis }\end{array}$ & & & 0.01 & & & & & & 0.01 \\
\hline $\begin{array}{l}\text { Rubus } \\
\text { parviflorus }\end{array}$ & 3.7 & 0.53 & & 0.67 & 1.72 & 0.37 & & 5.1 & 12.09 \\
\hline $\begin{array}{l}\text { Rubus } \\
\text { spectabilis }\end{array}$ & & & 5.08 & & 0.6 & & & & 5.68 \\
\hline Rubus ursinus & 3.39 & 33.5 & 3.9 & 6.79 & 0.9 & 12.93 & 3.99 & 1.5 & 66.9 \\
\hline $\begin{array}{l}\text { Sambucus } \\
\text { cerulea }\end{array}$ & & & & & & & & & 0 \\
\hline $\begin{array}{l}\text { Sambucus } \\
\text { racemosa }\end{array}$ & & 1.73 & 4.1 & & & & & & 5.83 \\
\hline $\begin{array}{l}\text { Salix } \\
\text { scouleriana }\end{array}$ & & & & 5 & & & & & 5 \\
\hline $\begin{array}{l}\text { Smilacina } \\
\text { racemosa }\end{array}$ & 2.68 & & 0.71 & & & & & & 3.39 \\
\hline $\begin{array}{l}\text { Sorbus } \\
\text { scopulina }\end{array}$ & & & & & 2.85 & & & & 2.85 \\
\hline $\begin{array}{l}\text { Symphoricarpos } \\
\text { albus }\end{array}$ & 10.53 & 0.95 & & & 2.02 & 2.25 & & & 15.75 \\
\hline $\begin{array}{l}\text { Taraxacum } \\
\text { officinale }\end{array}$ & & & & & & & & 0.1 & 0.1 \\
\hline $\begin{array}{l}\text { Tellima } \\
\text { grandiflora }\end{array}$ & 0.29 & & & & & & & & 0.29 \\
\hline Thuja plicata & & & & & 24.56 & & 12.72 & & 37.28 \\
\hline $\begin{array}{l}\text { Toxicodendron } \\
\text { diversilobum }\end{array}$ & & 6.86 & & & & & & & 6.86 \\
\hline $\begin{array}{l}\text { Tolmiea } \\
\text { menziesii }\end{array}$ & & & 1.05 & & & & & & 1.05 \\
\hline $\begin{array}{l}\text { Trientalis } \\
\text { borealis }\end{array}$ & & & & & 0.2 & & & & 0.2 \\
\hline Trillium ovatum & 0.13 & & 1.16 & 0.08 & & & & & 1.37 \\
\hline $\begin{array}{l}\text { Tsuga } \\
\text { heterophylla }\end{array}$ & 3.3 & & 4.2 & & & & & & 7.5 \\
\hline Taraxacum sp. & & 0.35 & & & & & & & 0.35 \\
\hline Urtica dioica & & & & & & & & 2.33 & 2.33 \\
\hline $\begin{array}{l}\text { Vancouveria } \\
\text { hexandra }\end{array}$ & 0.06 & & & 1.19 & & 1.37 & & & 2.62 \\
\hline $\begin{array}{l}\text { Vaccinium } \\
\text { parvifolium }\end{array}$ & & & & 4.61 & 2.85 & & & 1.59 & 9.05 \\
\hline Vicia americana & 2.63 & & & & & & & & 2.63 \\
\hline Vicia hirsuta & & & & & 0.4 & & & & 0.4 \\
\hline Vicia sativa & & & & & 0.2 & & & & 0.2 \\
\hline Viola glabella & 0.74 & & 2.28 & & & 0.1 & & & 3.12 \\
\hline
\end{tabular}

